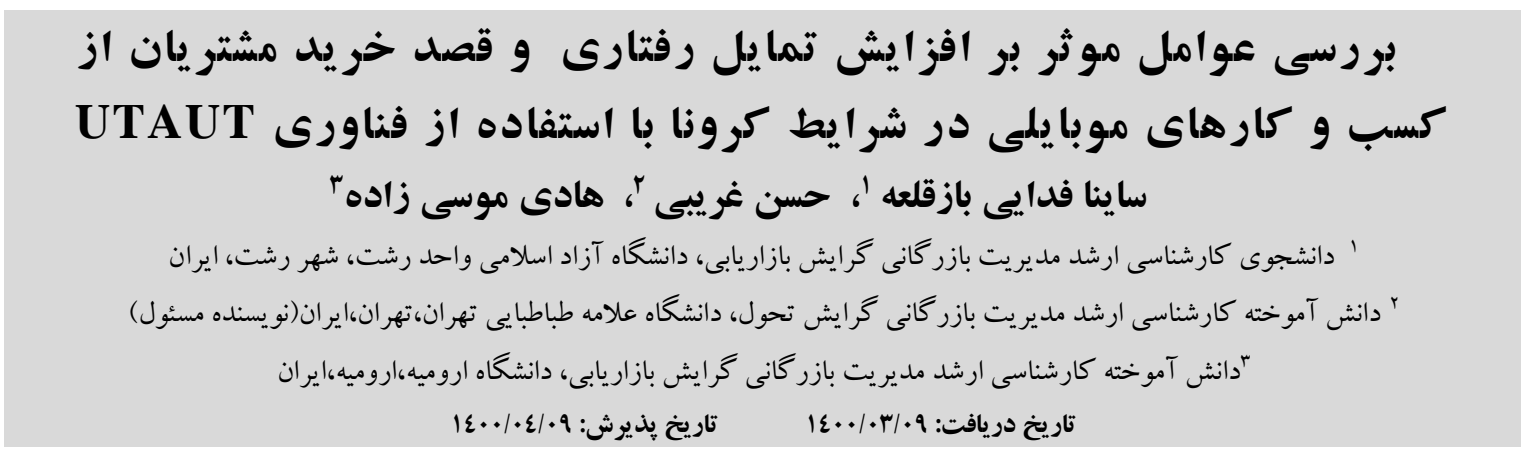

\title{
study the factors affecting the increase of behavioral desire and intention of customers to buy from mobile businesses in Corona using UTAUT technology \\ Saina Fadai Bazqaleh ${ }^{1}$, Hassan Gharibi ${ }^{2}$, Hadi Musazadeh ${ }^{3}$
}

${ }^{1}$ Master of Business Administration in Marketing, Islamic Azad University, Rasht Branch, Rasht, Iran

${ }^{2}$ Graduates of Transformational Business Management, Allameh Tabatabaei University, Tehran, Iran (Corresponding Author)

${ }^{3}$ Graduates of Business Administration in Marketing Orientation, Urmia University, Urmia, Iran Received: (30/05/2021) Accepted: (29/06/2021)

\section{شناسه يكتا}

\section{Abstract}

Today, with the epidemic of Corona, more and more people are turning to online shopping, and in the meantime, mobile businesses due to the availability of the Internet and the use of more smartphones; It has received more attention and the newness of these new businesses has caused companies active in this field to have less information about the factors affecting customer behavior and their behavioral tendencies. Therefore, the aim of this study was to investigate the factors affecting the increase in behavioral desire and intention of customers to buy from mobile businesses in corona using UTAUT technology throughout the country who have used mobile business services or products at least once; is. To investigate the study, a sample of 400 people was made available through the Telegram channel and the pages on Instagram and other virtual networks of Snap, Coin, Up, BafoodSoft and Bazaar applications. The results showed that Moore's efforts, expected performance, social influence and facilitating conditions were important factors for the company that mobile business owners can improve the desire of customers to buy mobile applications in Corona. . Keywords

Partnership, commitment, customer trust, customer loyalty,

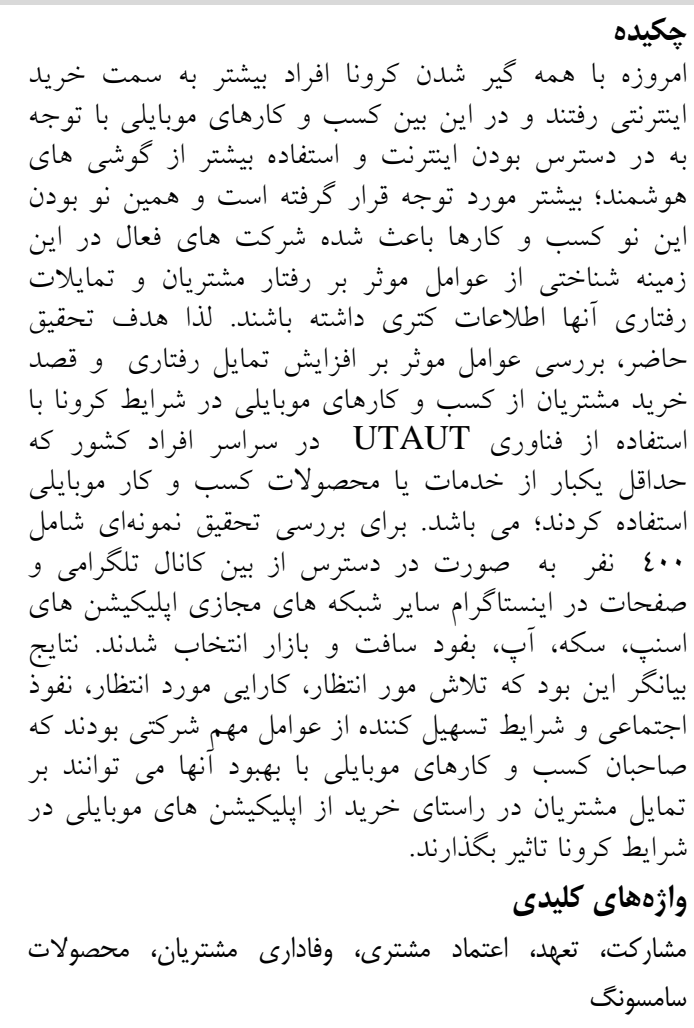


كار موبايلى، تمايل زيادى براى ورود به اكوسيسته ارائه

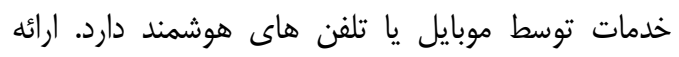

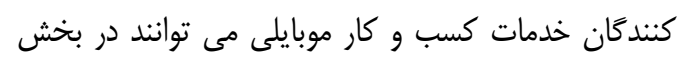

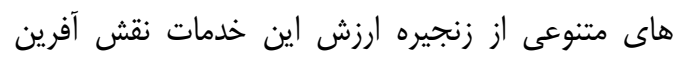

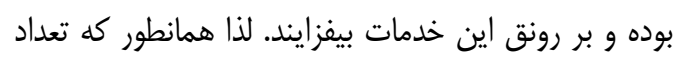

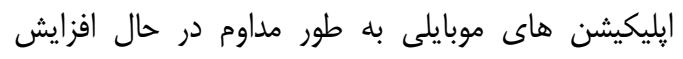

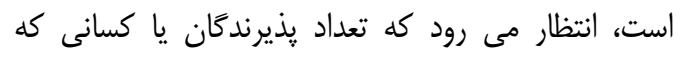

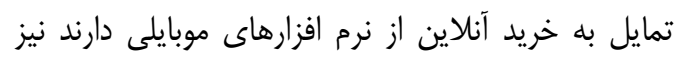

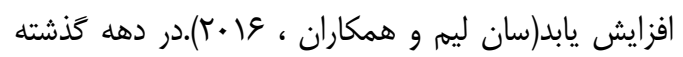

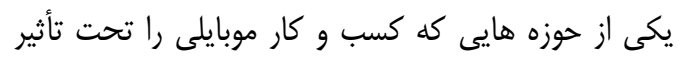

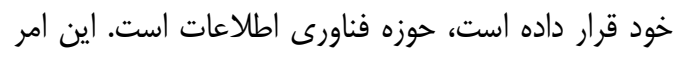

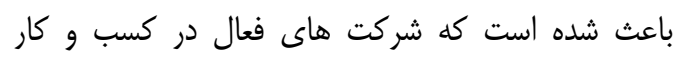

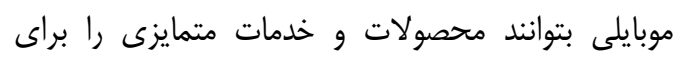

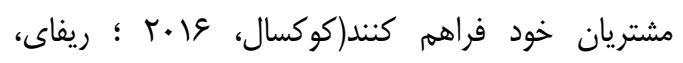

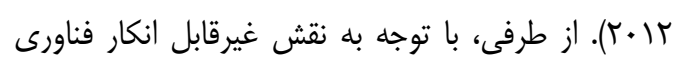

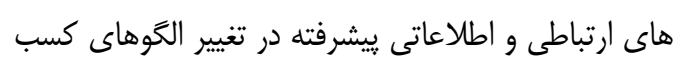

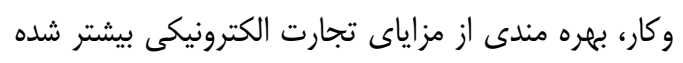

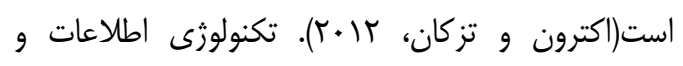

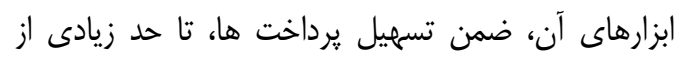

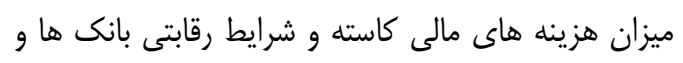

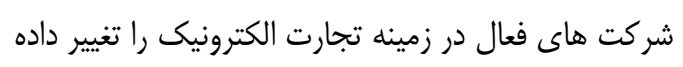

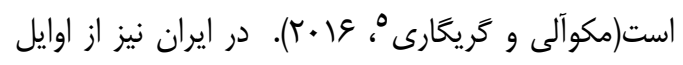

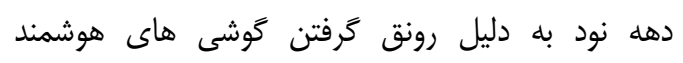

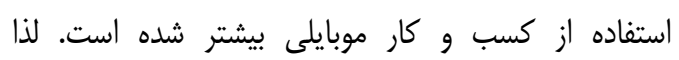
اهميت و ضرورت دارد كه شركت هاى فعال در اين زمينه

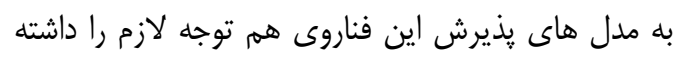

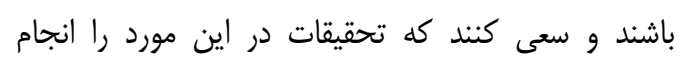
دهند.در نهايت مى توان كَفت كه بردئ كوسى عوامل اثر كذار

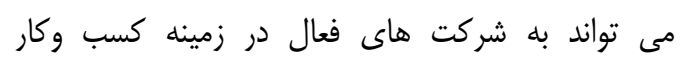

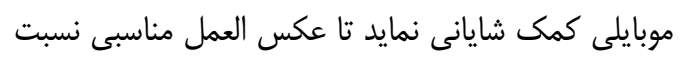

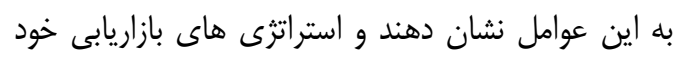

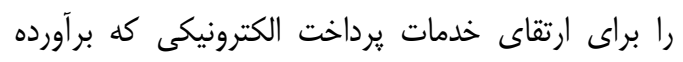

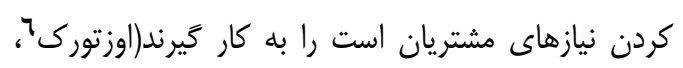

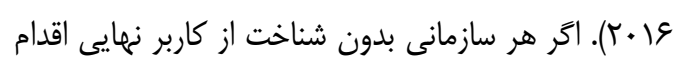

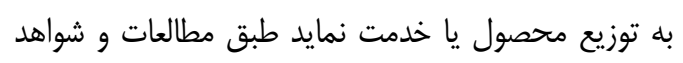

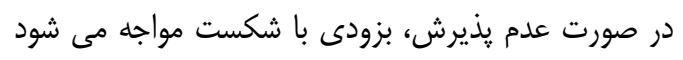

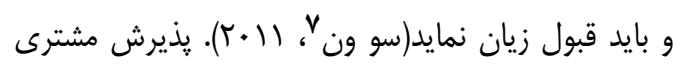

\footnotetext{
5 . Macaulay and gregory

6 . Ozturk

7. Su-Wen
}

مقدمه

تجارت الكترونيك از موضوعاتى است كه در سال هاى

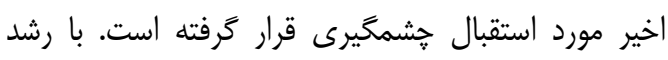

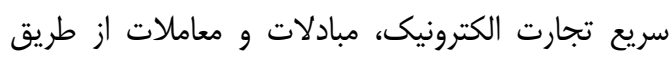

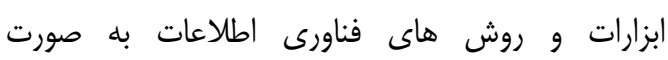

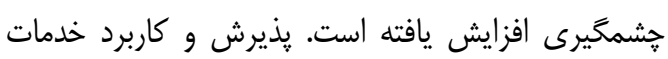

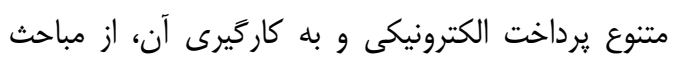

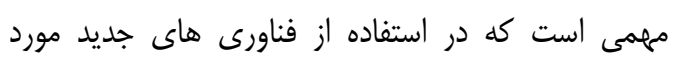

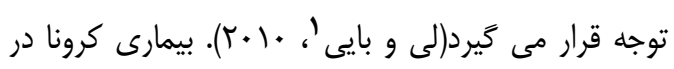

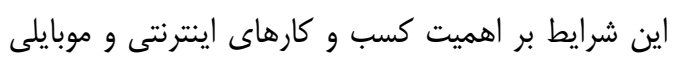

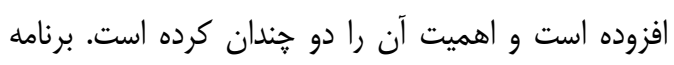

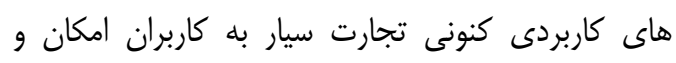

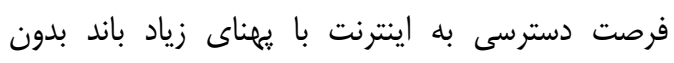

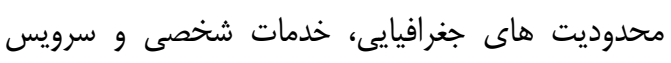

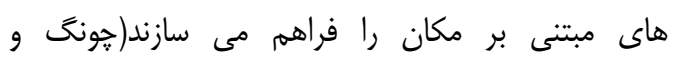

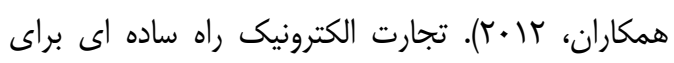

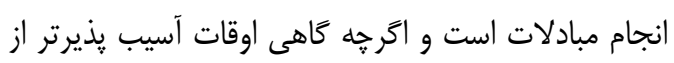

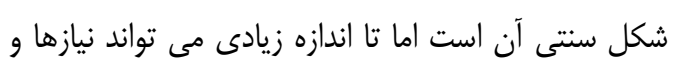

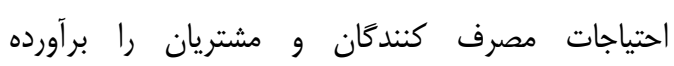

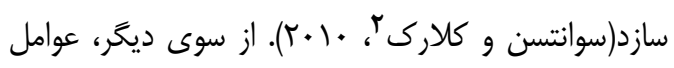

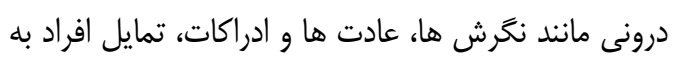

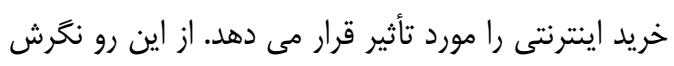

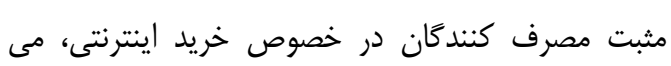

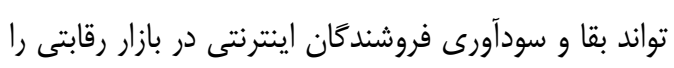

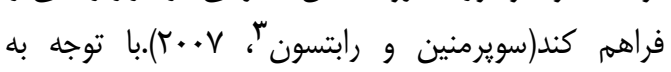

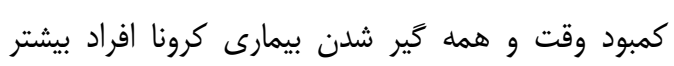

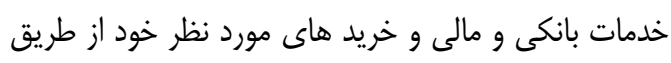

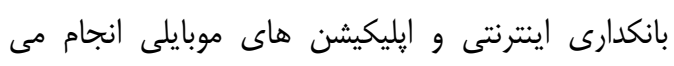

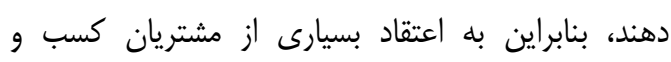

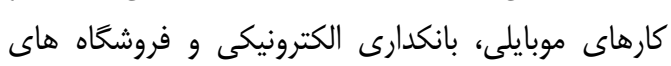

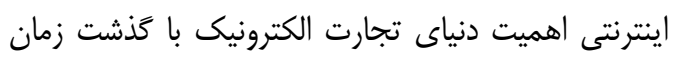

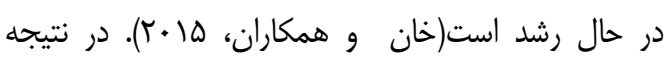

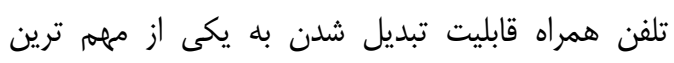

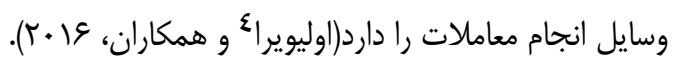

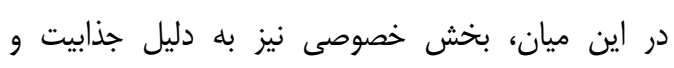

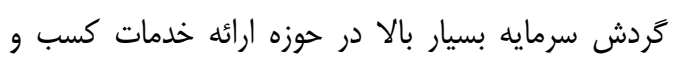

\footnotetext{
1. Li and Bai

2. Svantesson \& Clarke

3 . Soopramanien \& Robertson

4 . Oliveira
} 
توجه به حريم خصوصى ييش نيازهاى قبول تجارت

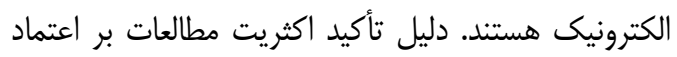

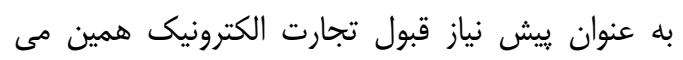

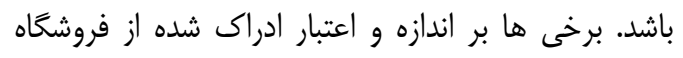

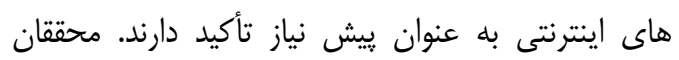

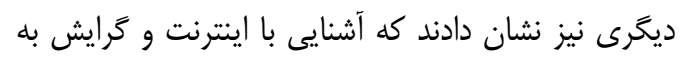

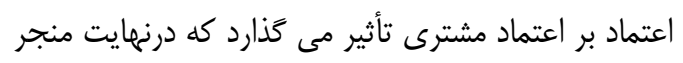

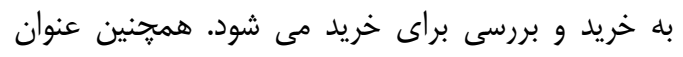
شده است كه درى مشترى از ميزان امنيت محيط وب نرئ نيز

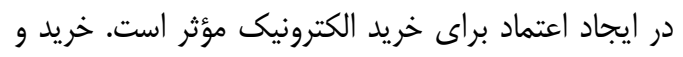

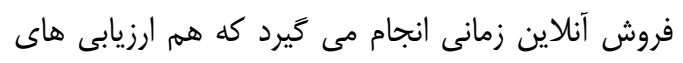

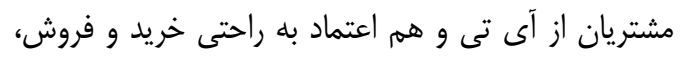

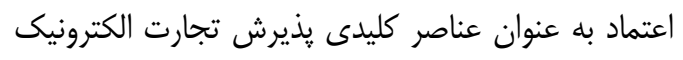

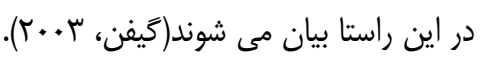

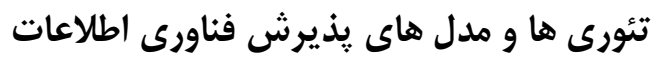

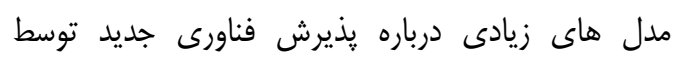

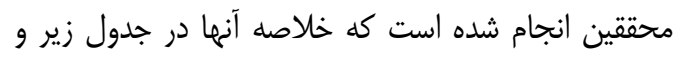
توضيحات آنها بيان شده است.
از يك تكنولوزى جديد يك يديده يِيجيده است كه نياز به

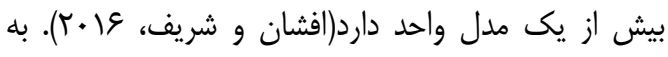

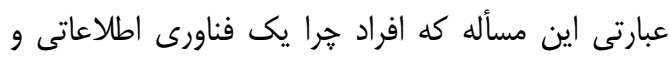

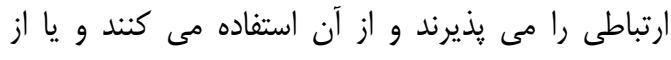

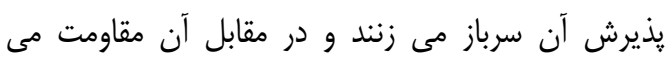

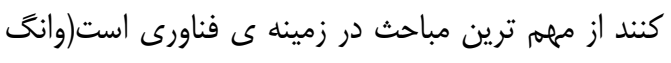

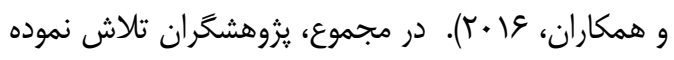

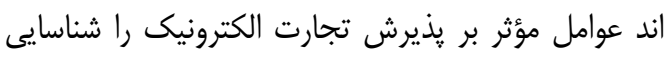

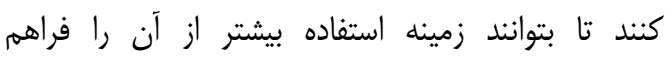

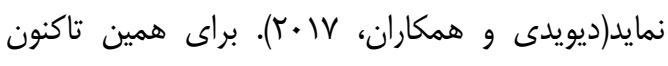

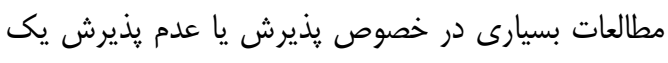

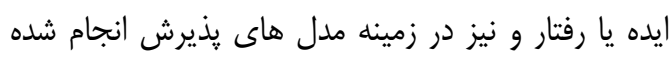

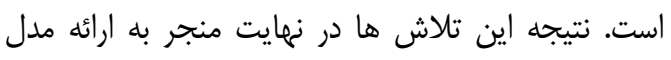

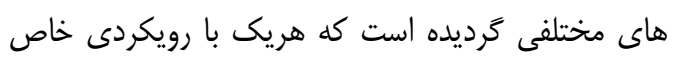

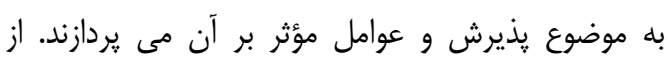

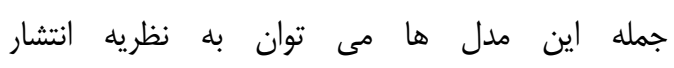

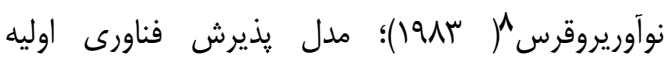

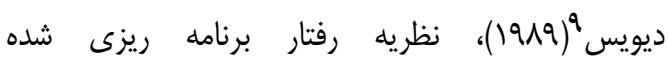

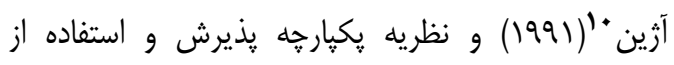

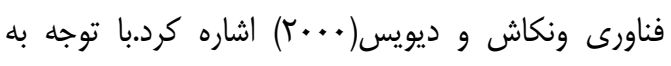

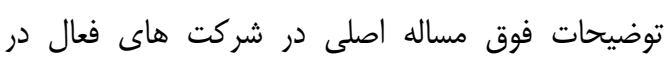

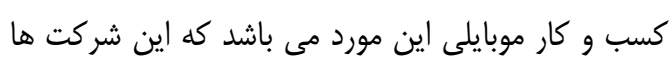
هنوز مدل يذيرش فناروى از طرف مشترى و و شناختى از مازي

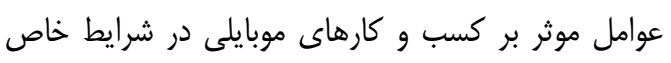

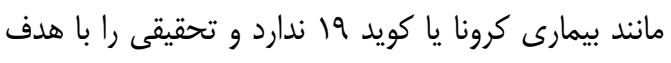

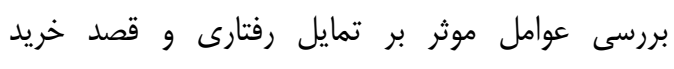

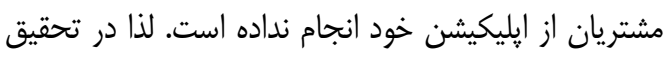

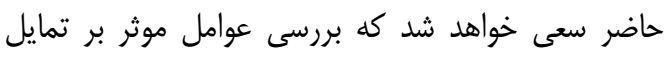

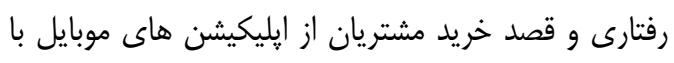

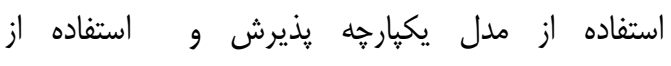

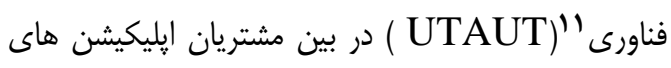
موبايلى در سراسر ايران بررسى شود.

ادبيات و بيشينه تحقيق دريق يذيرش تجارت الكترونيى توسط مشترى تحقيقات اخير

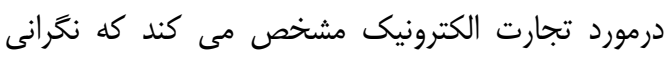

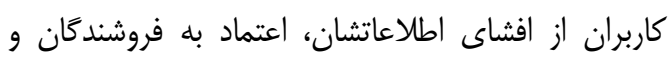

\footnotetext{
8 . Rogers

9 . Davis

${ }^{10}$. Ajzen,

${ }^{11}$.Unified Theory of Acceptance and Use of Technology
} 
تلاش مورد انتظار "1 : ميزان سهولت استفاده از سيستم را نشان مى دهد؛ و شامل سه بعد سهولت استفاده ادراك

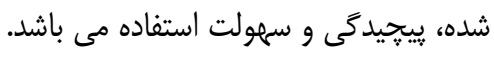

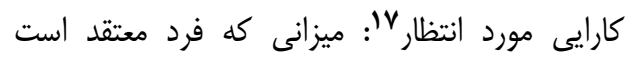

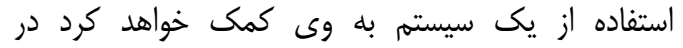

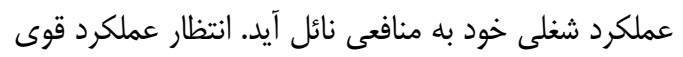
ترين بيش بينى در قصد استفاده از فناورى اطلاعات و

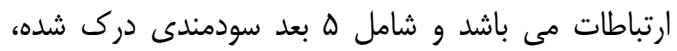
انخيزه بيرونى، تناسب شغلى، مزاياى مرتبط و انتظار نتيجه مى باشد. نفوذ اجتماعى ^ا": ميزانى كه يكى فرد ادراك مى كند افراد مهم ديخر معتقدند او بايد از سيستم جديد استفاده

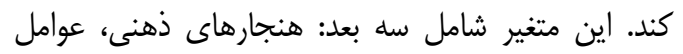
اجتماعى و تصوير مى باشد. شرايط تسهيل كننده 19: ميزانى كه فرد معتقد است زيرساخت هاى فنى و سازمانى لازم براى يشتيبانى از

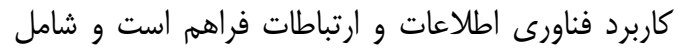

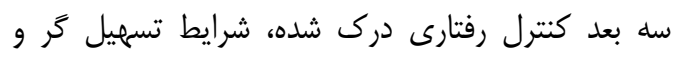

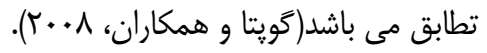

\section{كرونا و كسب و كارهاى اينترنتى مانند إيليكيشن}

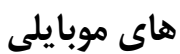

يكى از تاثيرات مثبت كرونا بر كسب و كارهاى غير برخط

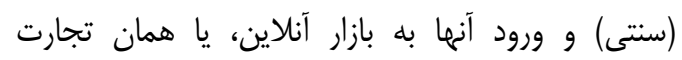

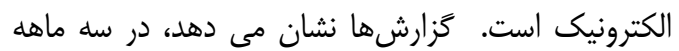

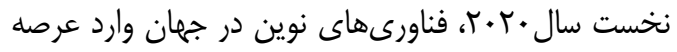

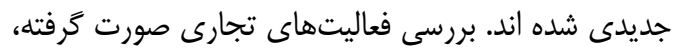

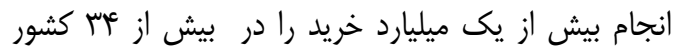

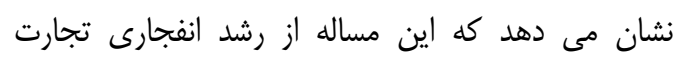
الكترونيك در سراسر جهان حكايت دارد. بهان بان باور

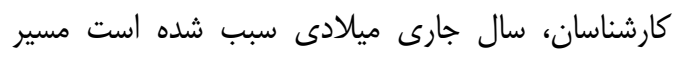

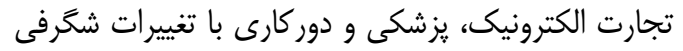
روبرو شود. بررسى يافتهاى كليدى شاخص خريد در سه ماهـ

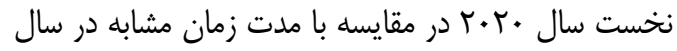

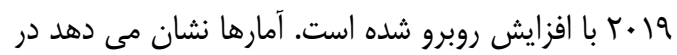

\footnotetext{
${ }^{16}$ Effort Expectancy

${ }^{17}$ Performance Expectancy

${ }^{18}$ social influences

19 facilitating conditions
}

جدول (: خلاصه مدل هاى عمومى يذيرش فناورى جديد

\begin{tabular}{|c|c|c|c|}
\hline محقق & عوامل & سال & مدل \\
\hline فيش بين و آزين & نَكرش، هنجار & $19 \vee \Delta$ & نظريه رفتار منطقى \\
\hline راجرس זّا & 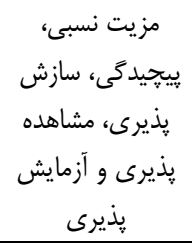 & $191 \%$ & $\begin{array}{l}\text { نظريه انتشار نوآورى } \\
\text { (IDT) }\end{array}$ \\
\hline ديويس \&1 & و نحرش شهولت استفاده & 1919 & 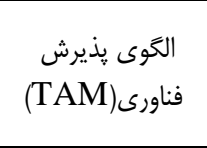 \\
\hline آرَين & ذنخرش، هنجار كنترل & 1991 & ريزى شدهـ(TBP) \\
\hline همكاران و & انخيَز ش درونى، & 1995 & $\begin{array}{c}\text { الكَوى انكَيزشى (MM) } \\
\text { (MM) }\end{array}$ \\
\hline همكاران 10 & 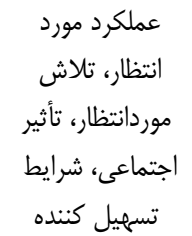 & $r . . r$ & 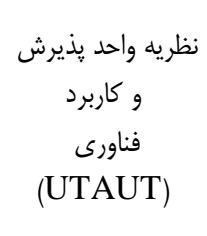 \\
\hline ونكارانش و & 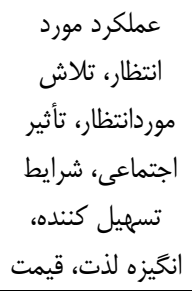 & $r \cdot I r$ & 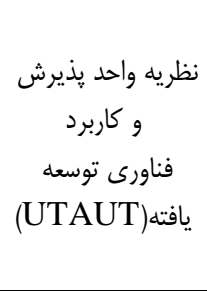 \\
\hline
\end{tabular}

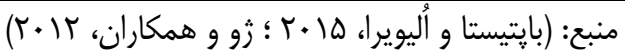

\section{نظريه واحد يذيرش و كاربرد فناورى}

(UTAUT)

حاصل تلاش ونكاتش و همكاران (r.+r) مى باشد كه

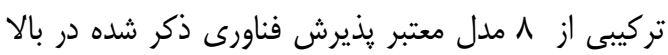

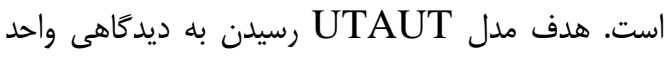
در يذيرش فناورى اطلاعات و ارتباطات است(ديويدى و لهيد

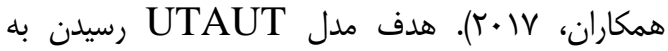

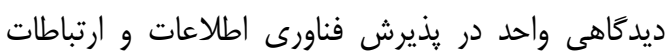

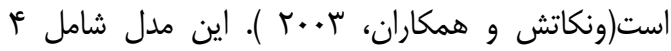
بخش كليدى مى باشد:

\footnotetext{
12. Fishbein and Azjen

13 . Ragers

14. Davis

15. Venkatesh et al.
} 
استخدام كاركران جديد، امكان تامين، دريافت و تحويل

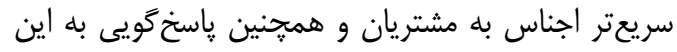
تقاضاى رو به افزايش را فراهم كرده است.

ييشينه تحقيق

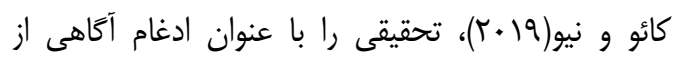
مفهوم UTAUT براى توضيح يذيرش كاربران

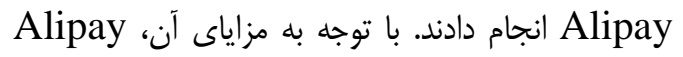

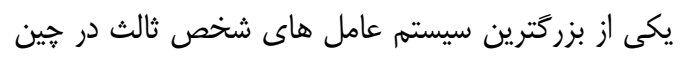

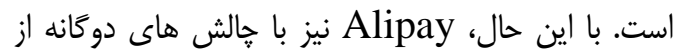

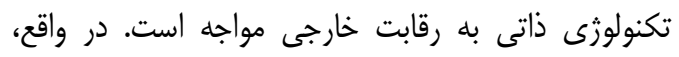

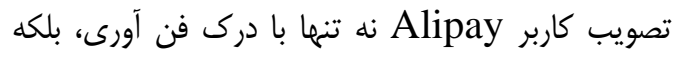

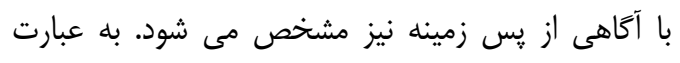

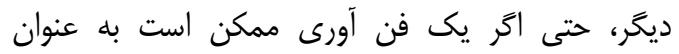

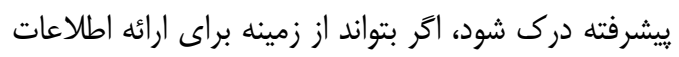

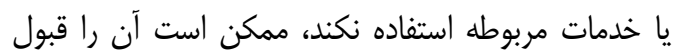

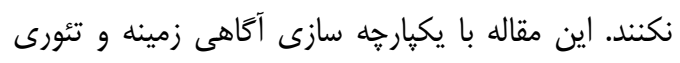

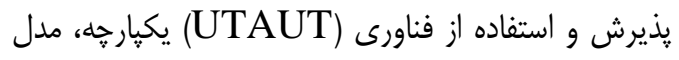

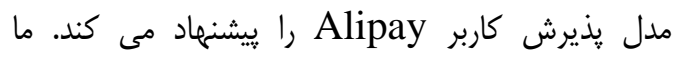

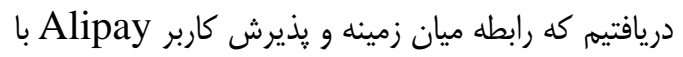

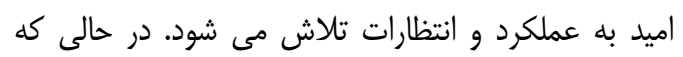

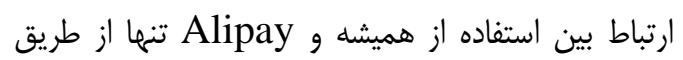
اميد به عملكرد، متاثر مى شود.

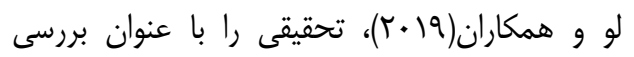

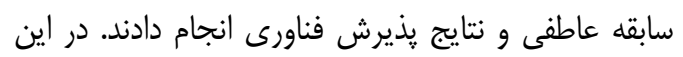

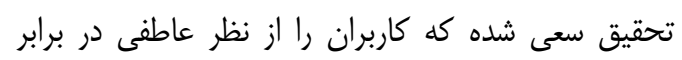

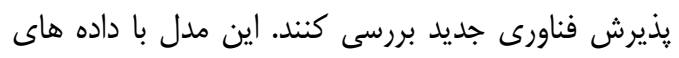

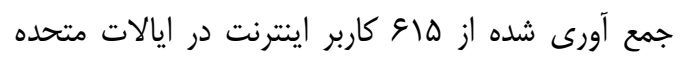

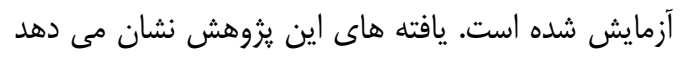

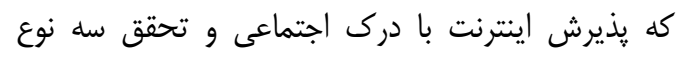

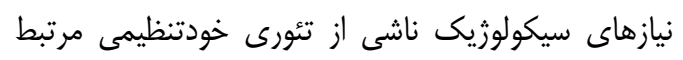

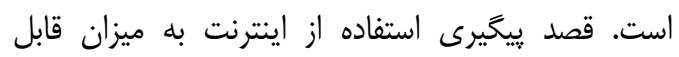

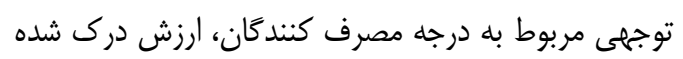

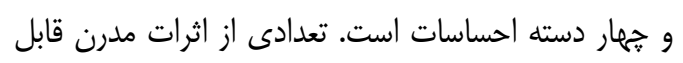

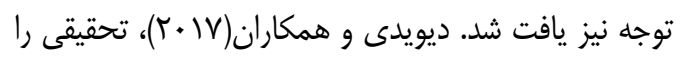

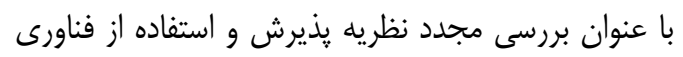

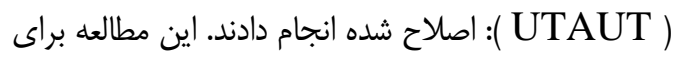

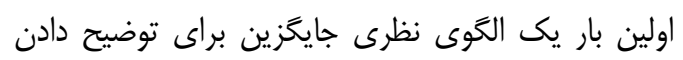

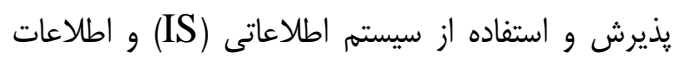

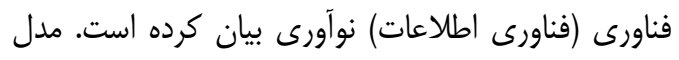

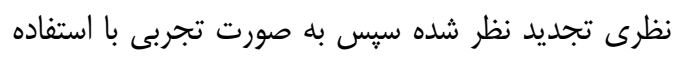

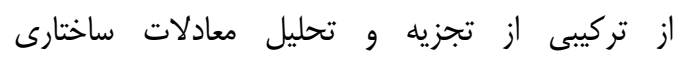

سه ماه نخست •r.Y.T به سبب شيوع ويروس كرونا،

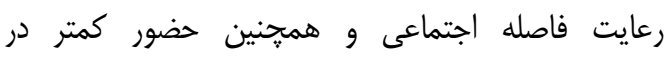

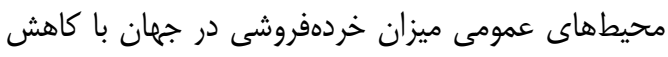

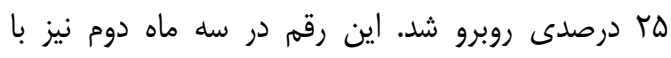

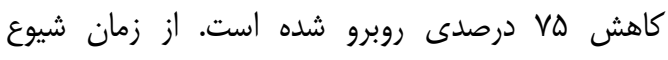

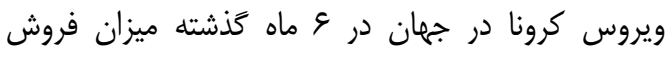

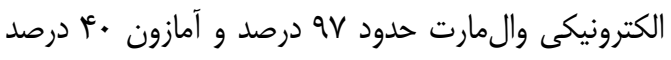

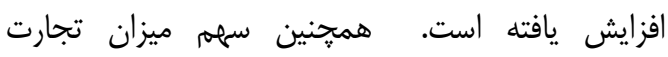

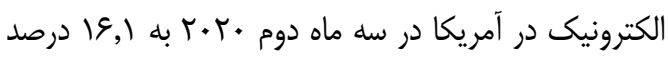

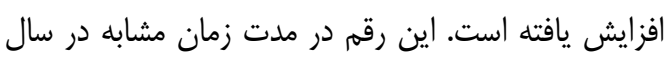

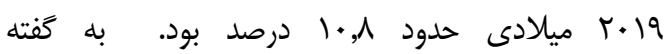

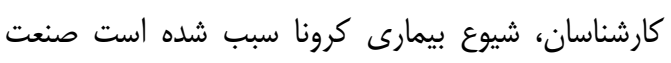

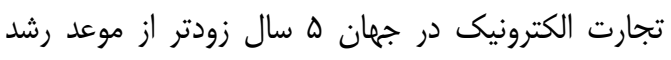
كند. ييش بينى شده در سال •r.r.r. ميزان خردهفروشى

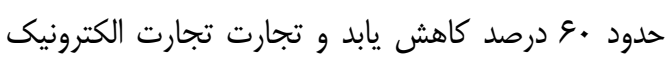

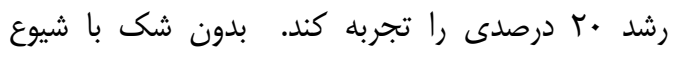

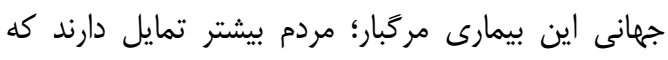

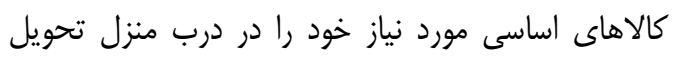

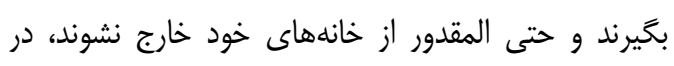

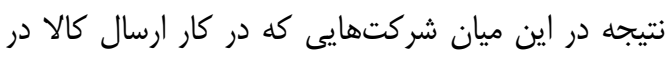

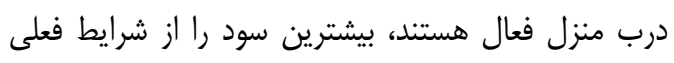

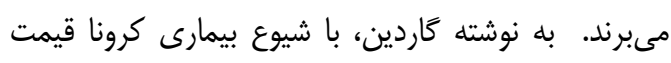

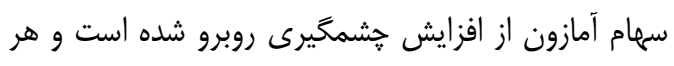
روز به قيمت سهام اين شركت افزوده مي شئردي.

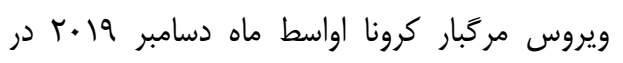

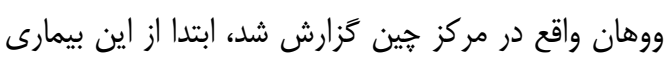

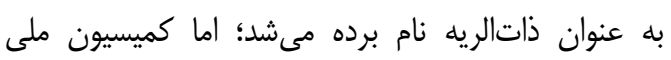

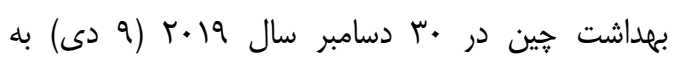
صورت رسمى شيوع اين ويروس را در جين دين اعلام كرد.

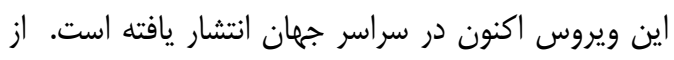

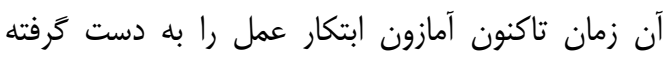

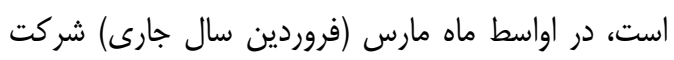

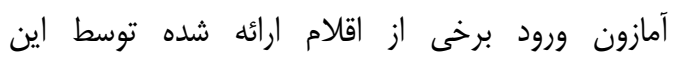

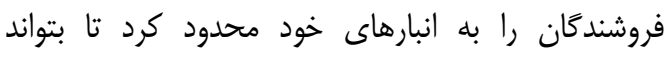

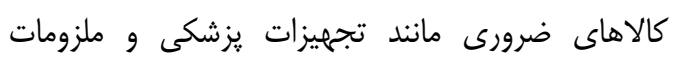

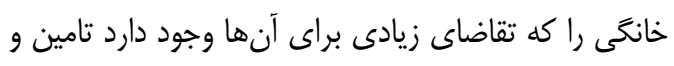

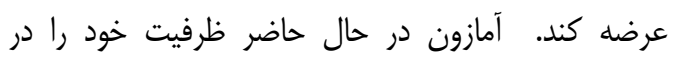

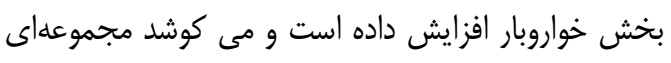

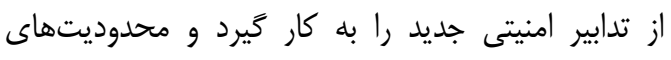

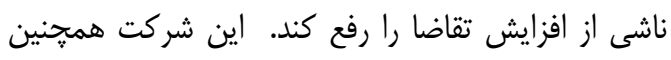


آزمايش قرار كرفته است. نتايج نشان داده كه انتظار

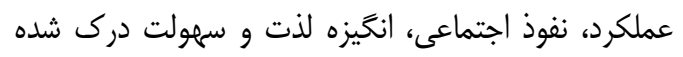

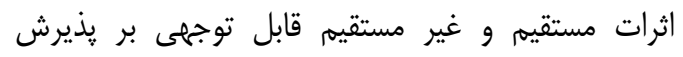

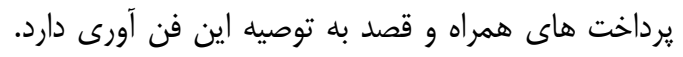

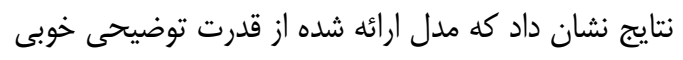
براى ييش بينى قصد مصرفكننده به اتخاذ برداخت همراه

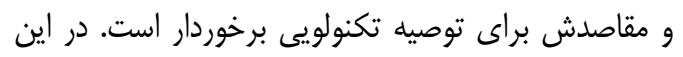
تحقيق ارتباط با قصد مشترى به توصيه تكنولوزى در در برد

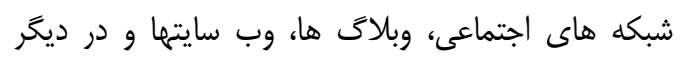

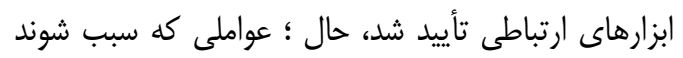

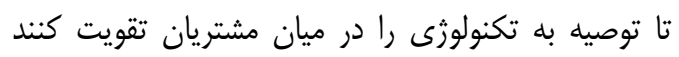
ميتواند زمينه اى براى مطالعات آينده باشد.

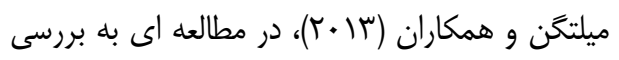

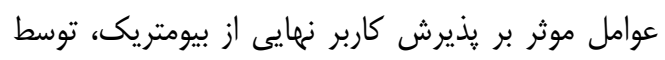

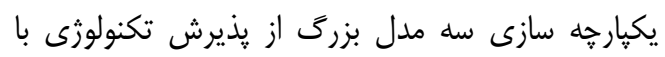

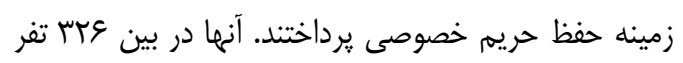

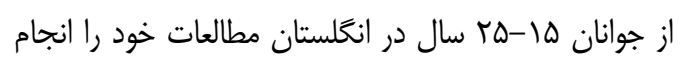

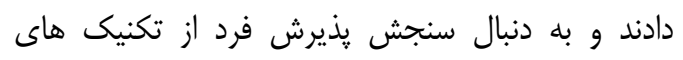

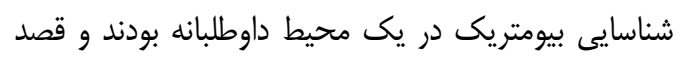

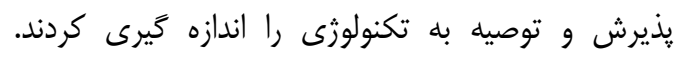

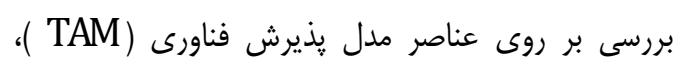

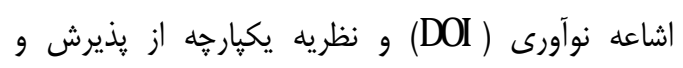
استفاده از تكنولوزى(UTAUT) همراه با متغير حريم خصوصى انجام شد، كه دو نتيجه مهرم بدست آمده است.

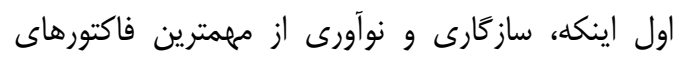

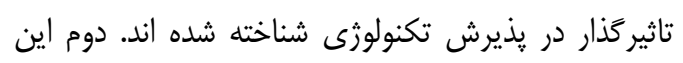

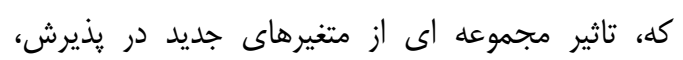

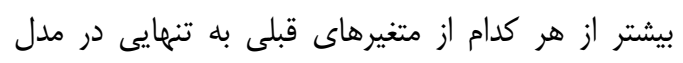

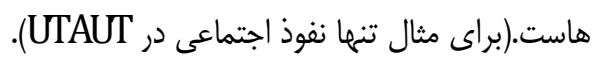

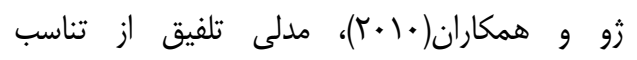

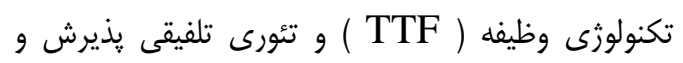

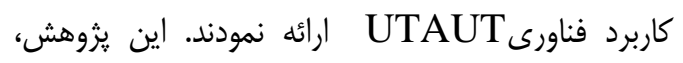

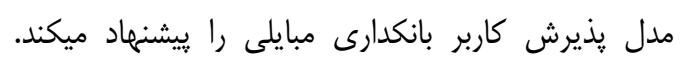
نتايج نشان دادند كه معيارهاى عملكرد اجرا موري مانكاري مارد انتظار،

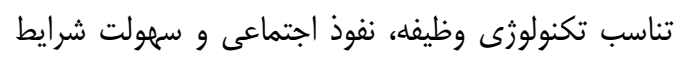

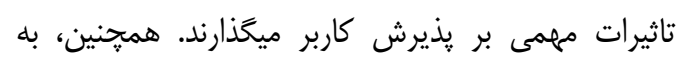

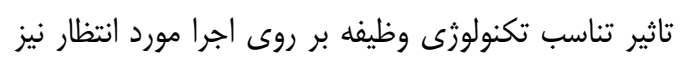

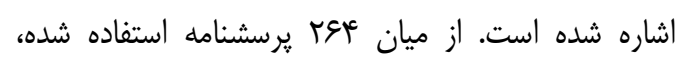

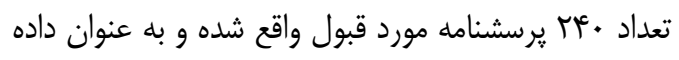

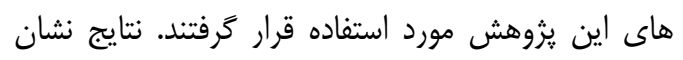

تكنيك آن مورد بررسى قرار گرفت. روش (MASEM)

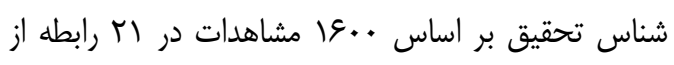

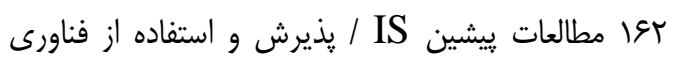

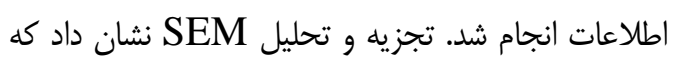

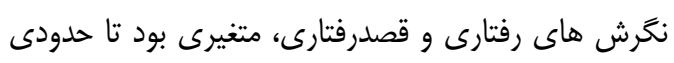

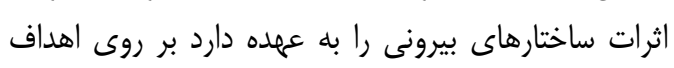

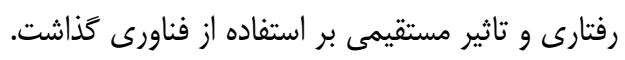

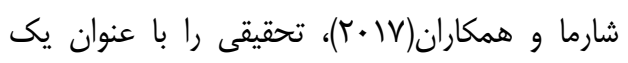

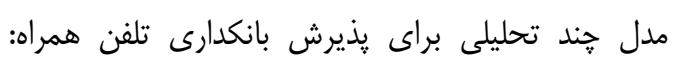

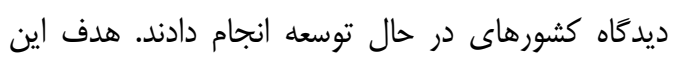

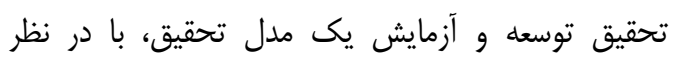

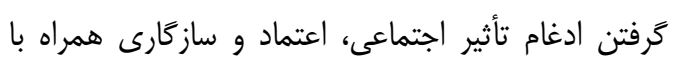

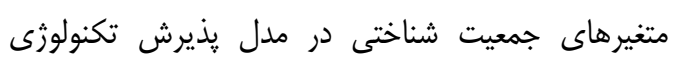

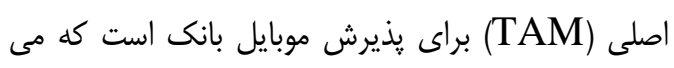

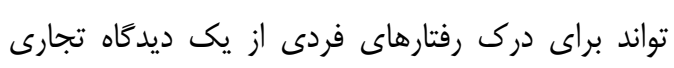

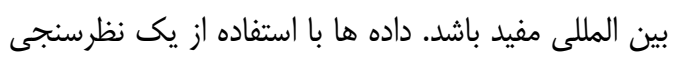

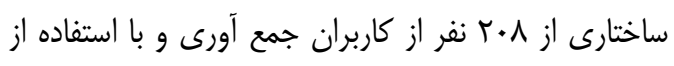

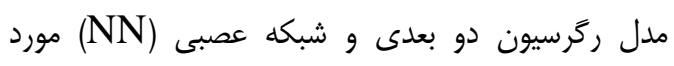

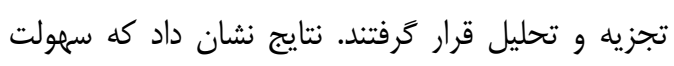

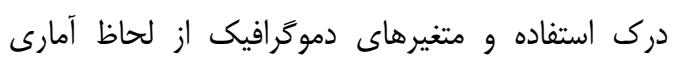

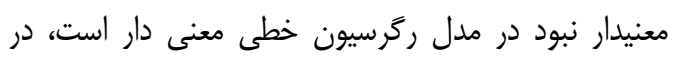

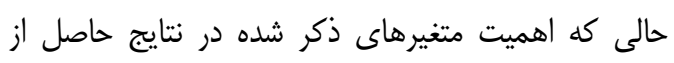

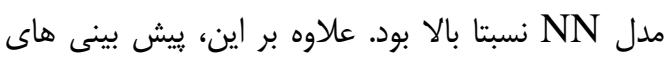

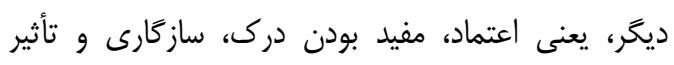
اجتماعى كه در مدل تحقيق ييشنهادى موجود بودي، با توجه بوني

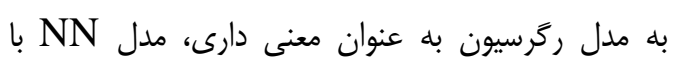

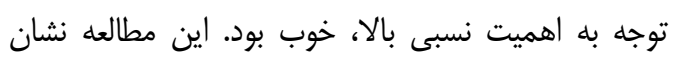

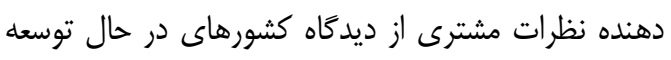

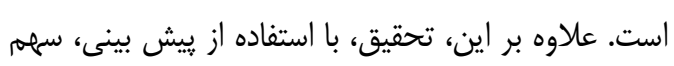

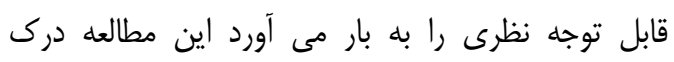

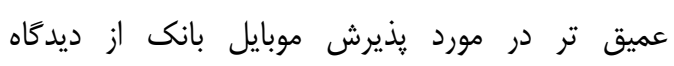
كشورهاى در حال توسعه را نشان مى دهى دهد و و متغيرهاي

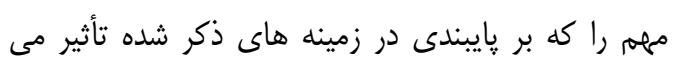
كذارد شناسايى و ادغام مى كند.

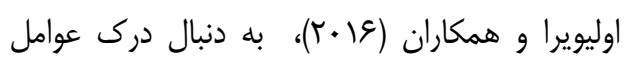

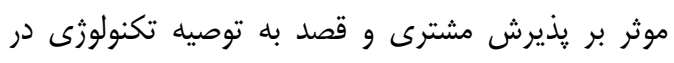

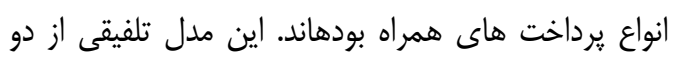

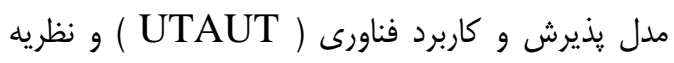

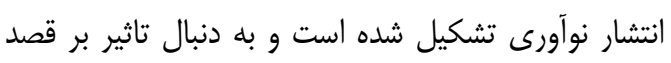

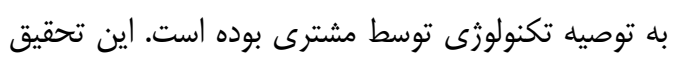
با نظرسنجى از ا•• نفر در كشور ارويايى يرتغال مورد 
اينترنتى است را وارد مدل اوليه نموده اند. اين تحقيق تأثير خوداتكايى رايانه اى را بر قصد رفتارى كاربران از طريق إنتيق

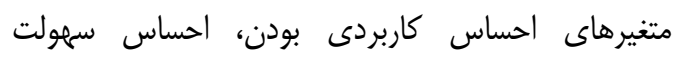
كاربرى و احساس اعتماد نشان ميدهد. متغير احساس

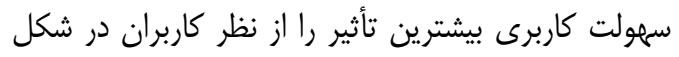

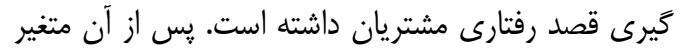
احساس اعتماد در رتبه بعدى و متغير احساس كاربردى بودن در رتبه آخر قرار كرَفت.

\section{مدل مفهومى تحقيق} در مدل مفهومى تحقيق حاضر سعى شده است كه تاثيث

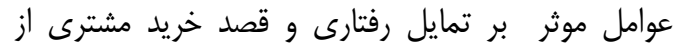

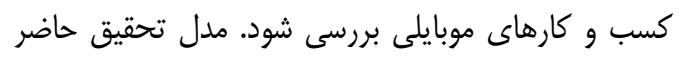

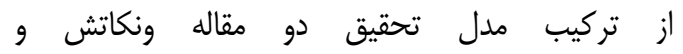

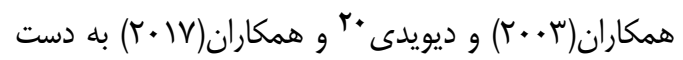
أمده؛ بنابراين در تحقيق حاضر نيز از مدل يكيارجها

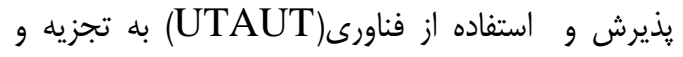

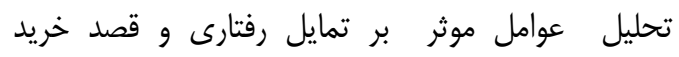
مشتريان در شرايط كرونا از كسب و كارهاى موبايل يرداخته خواهد شد.

\section{شكل (.مدل مفهومى تحقيق}

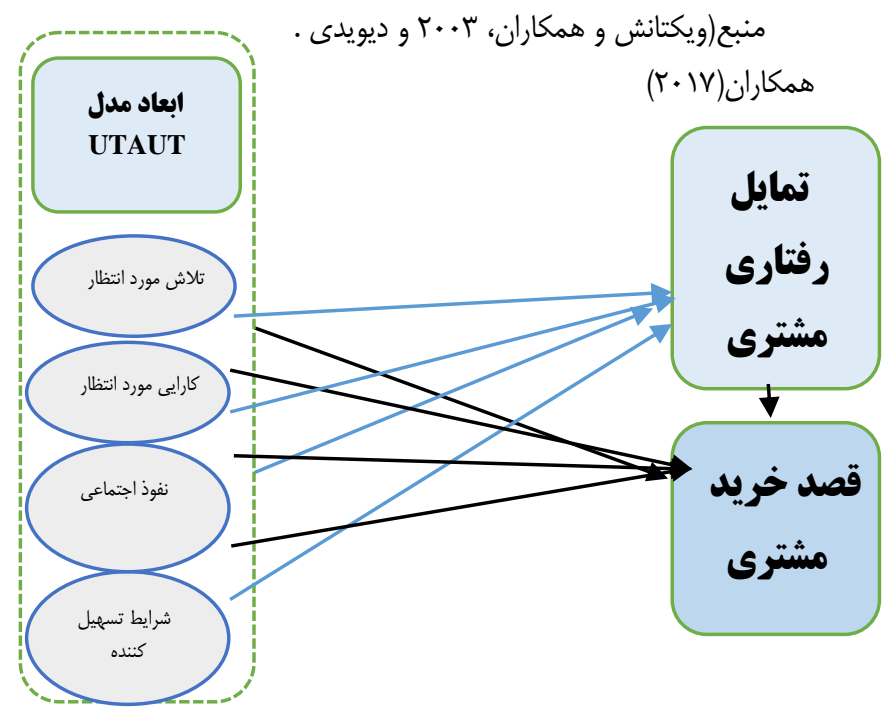

دادند كه هر دو مشخصه تكنولوزى و وظيفه قويا بر تناسب تكنولوزى وظيفه تاثير ميكذارند كه بذيرش كاربر

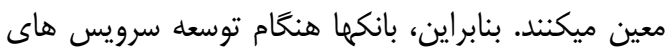
بانكدارى مبايلى ميبايستى تناسب بين ييش نياز

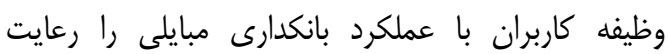

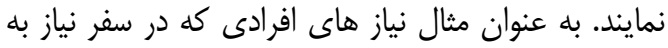

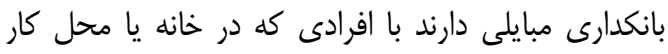
خود هستند متفاوت است. هميجنين، نتايج ارتباط بين

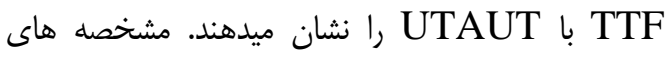
تكنولوزى به طور قوى بر انتظار تلاش تاثير كذاشته و تناسب تكنولوزى وظيفه هم اثر واضحى بر انتظار اجرا

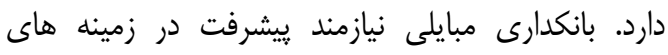

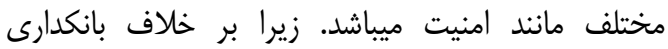

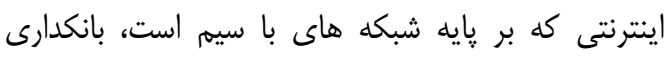

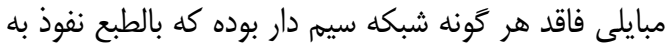

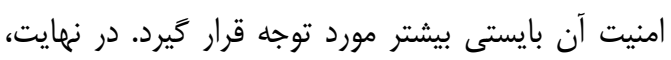

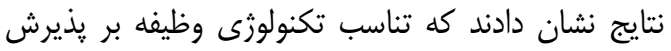

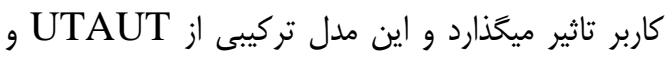

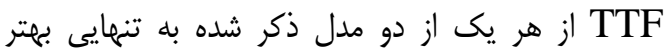
ميتواند يذيرش كارير را تفسير نمايد.

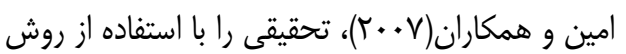
يذيرش تكنولوزى و به منظور شناسايى عواملى كه تصميم

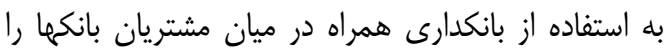

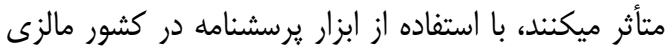

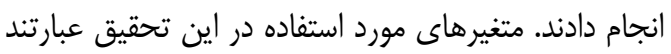
از: اعتبار درك شده، سهولت استفاده درك شده، خودباورى درك شده و فشار اجتماعى. نمونه آمارى مورد استفاده در دري اين تحقيق شامل مشتريان بانك در كشور مالزى بودند كه

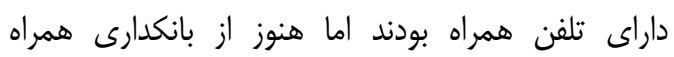

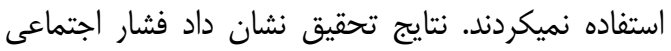

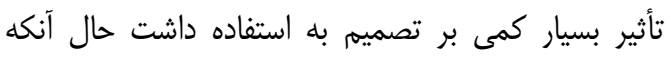
سهولت استفاده تأثير قابل ملاحظه ایى بر اين تصميه

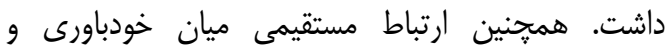
تصميم به استفاده از بانكدارى همراه و تأثير مثبتى ميان

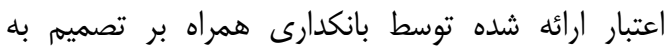
استفاده از بانكدارى همراه ملاحظه كَرديد.

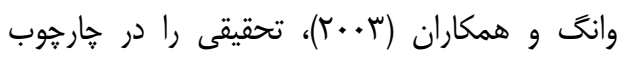

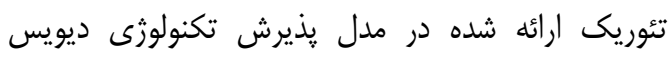

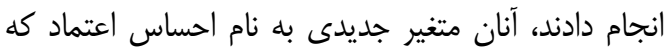

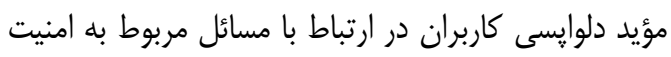

و حريم خصوصى در اتخاذ تصميم براى بذيرش بانكدارى إنى

${ }^{20}$ Dwivedi 
سكه، آب، فود سافت و بازار) را داشتند؛ مىباشد. با توجه

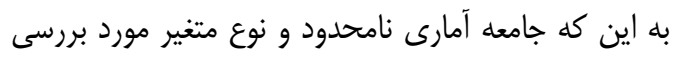
كيفى است، از رابطه زير اقدام به محاسبه و تعيين حجانم

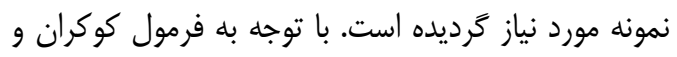

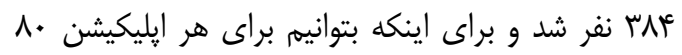

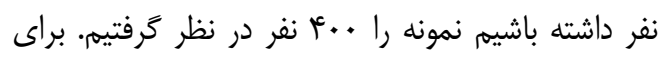

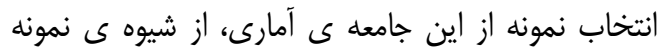
كيرى غير تصادفى در دسترس استفاده شده است. بدين إندان

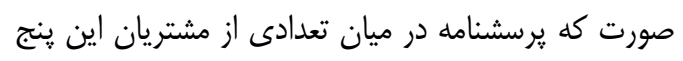

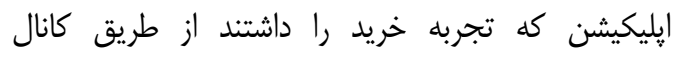

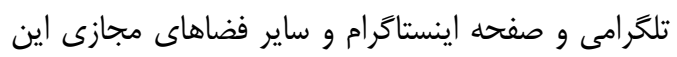
فروشگاه هاى موبايلى توزيع شد.

يرسشنامه

קرسشنامه مذكور شامل r بخش عمده مى باشد:

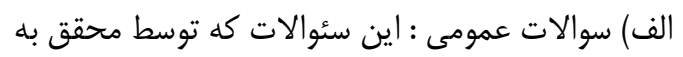
يرسشنامه اضافه كَرديده است. در سوالات عمومى سعى التى شده است كه اطلاعات كلى و جمعيت شناختى در رابطه

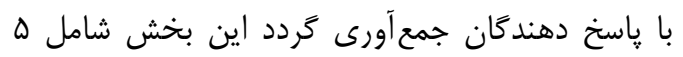

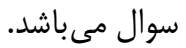
ب) سوالات تخصصى: اين بخش شامل • ب سوال است

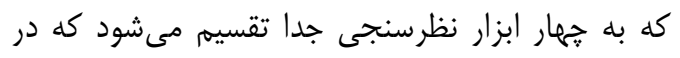
جدول زير تفكيك شده بيان شده است.

\section{فرضيه هاى تحقيق}

- - تلاش مورد انتظار بر تمايل رفتارى مشترى تاثير دارد. - كارايى مورد انتظار بر تمايل رفتارى مشترى تاثير دارد. - - نفوذ اجتماعى بر تمايل رفتارى مشترى تاثير دارد. - نماري

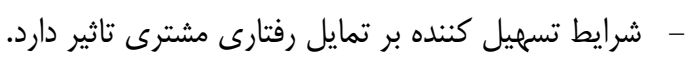

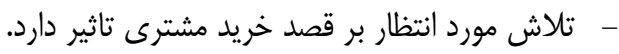

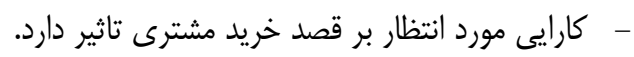
- ن نفوذ اجتماعى بر قصد خريد مشترى تاثير دارد.

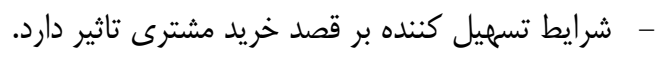
- تمايل رفتارى مشترى بر قصد خريد مشترى تاثير دارد.

\section{روش شناسى تحقيق}

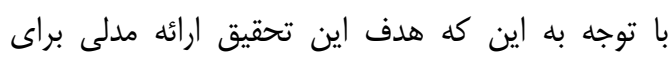

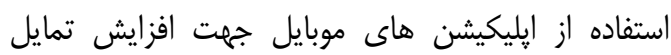

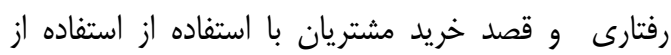

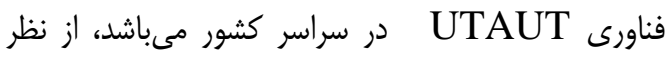

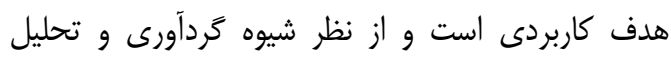

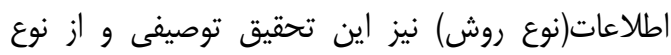

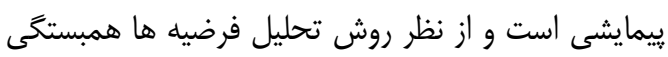

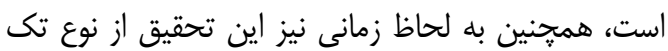
مقطعى مى باشد.

\section{جامعه آمارى و حجم نمئ بأند}

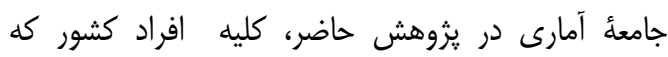
حداقل يكبار استفاده از إيليكيشن موبايلى خريدا(اسني، إنه

جدول (. شاخص هاى يرسشنامه

\begin{tabular}{|c|c|c|c|}
\hline منبع & سوالات & شاخص & 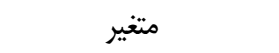 \\
\hline \multirow{4}{*}{ 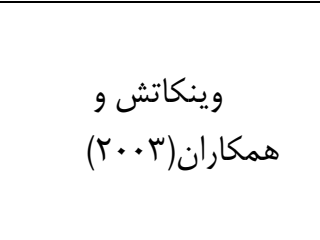 } & $f-1$ & تلاش مورد انتظار & \multirow{4}{*}{$\begin{array}{c}\text { فناورى(UTAUT) } \\
\text { (UTAT) }\end{array}$} \\
\hline & $V-\Delta$ & كارايى مورد انتظار & \\
\hline & $11-\wedge$ & نفوذ اجتماعى & \\
\hline & $14-14$ & شرايط تسهيل كننده & \\
\hline ديويدى و همكاران(VIV) & $10-1 V$ & - & تمايل رفتارى مشترى \\
\hline ديويدى و همكاران(Y) & $M-r$. & - & قصد خريد مشترى \\
\hline
\end{tabular}

است

ب1 : توزيع دادهاى مربوط به هر يك از متغيرها نرمال نيست.

زمانى كه توزيع متغيرها نرمال است جهت آزمون فرضيات

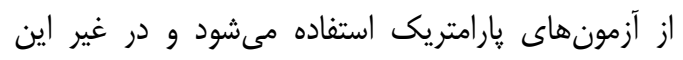
صورت آزمون هاى نايارامتريى مورد استفاده قرار مى إمى إنى
سنجش نرمال بودن توزيع متغيرها

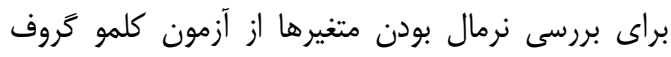

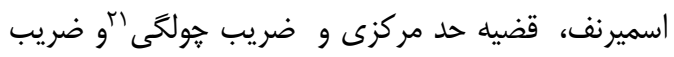
كشيدگى "rا استفاده شده است.

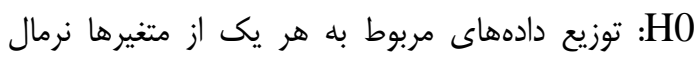

\footnotetext{
${ }^{21}$ Skewness

${ }^{22}$ Kurtosis
} 
ت است. اين ضريب به كونه اى (r Correlation

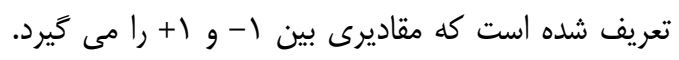

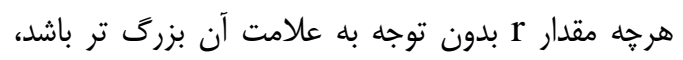

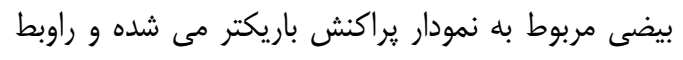

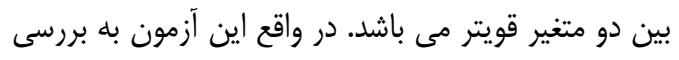
فرضيه زير مى فيردازد:

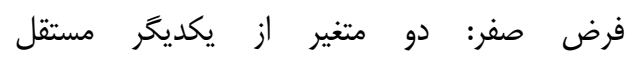

$$
\text { هستند) }
$$

فرض مقابل: دو مت متغير با يكديگر ارتباط

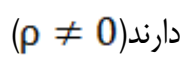

جدول زير ماتريس ضرايب همبستخى بين متغيرهاى مورد مطالعه را نشان مى دهد.
كيرد. جهت بررسى نرمال بودن از ضرايب هولنى "rآو

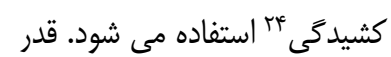

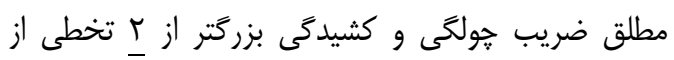
نرمال بودن داده ها را نشان مى دها دهد. جدول r. نتايج آزمون نرمال بودن آنس دهل داده ها

\begin{tabular}{|c|c|c|c|c|c|}
\hline نتيجه & & شاخد & ضشريب & ضريَ & تحتيرهاى \\
\hline & مد & ميانگين & & & \\
\hline זرد نرمال & je & ґ,ఎ. & • & $-\cdot, \Delta T$ & تلاش مورد \\
\hline نرمال & f & r. r. & $\cdot,+\varphi$ & $-\bullet, \Delta q$ & مورد ارنتار \\
\hline نرمال & f & $r, \Delta T$ & $\cdot,+1$ & $-\cdot, \varphi^{\mathrm{T}} \mathrm{V}$ & اجتماعى \\
\hline نرمال & r & $\cdot r, \mathrm{r} \cdot$ & $\cdot, \mathrm{VV}$ & $-\cdot,(\mathrm{V})$ & شنسايط \\
\hline نرمال & r & سو.r & $\cdot, \mathrm{VV}$ & -.99 & مشترى \\
\hline نرمال & $f$ & 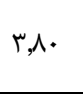 & צז, • & $-\cdot, \mathrm{\wedge} \wedge$ & قصد خريد \\
\hline
\end{tabular}

همانطور كه در جدول فوق مشخص است ، مقدار ضريب

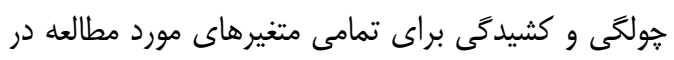

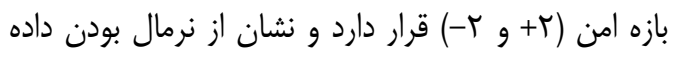

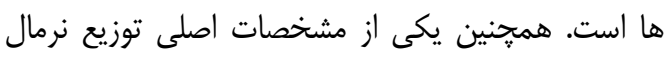

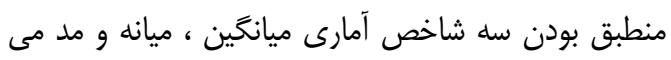

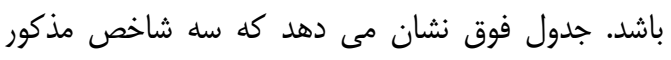

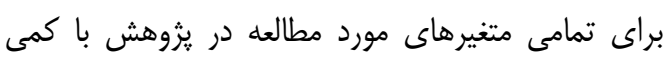

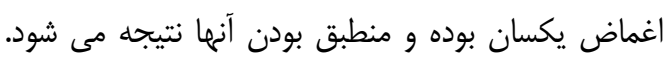

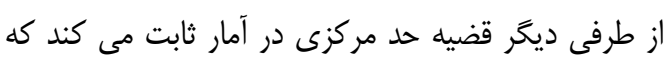

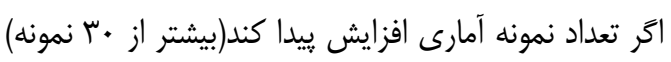
توزيع داده ها به سمت توزيع آمارى نرمال سوق دادئ دادئ

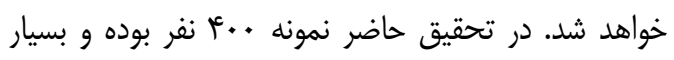
مطلوب مى باشد.

\section{ضر يب همبستكى بيرسون بين متغيرها}

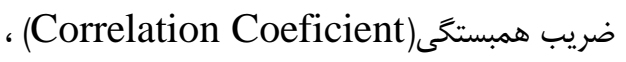
آماره اى است كه جهت اندازه گيرى قدرت يا درجه

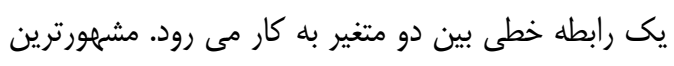

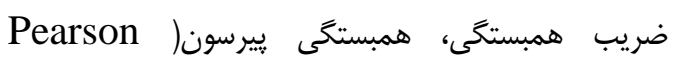

\footnotetext{
${ }^{23}$ Skewness

${ }^{24}$ Kurtosis
} 
جدول س. ضرايب همبستكى ييرسون بين متغيرهاى اصلى تحقيق

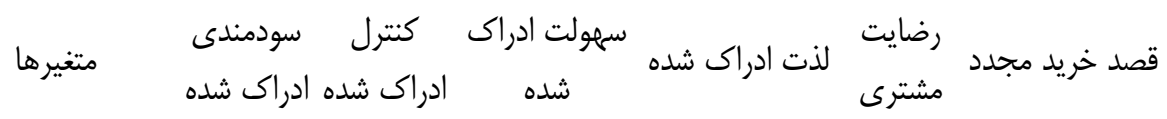

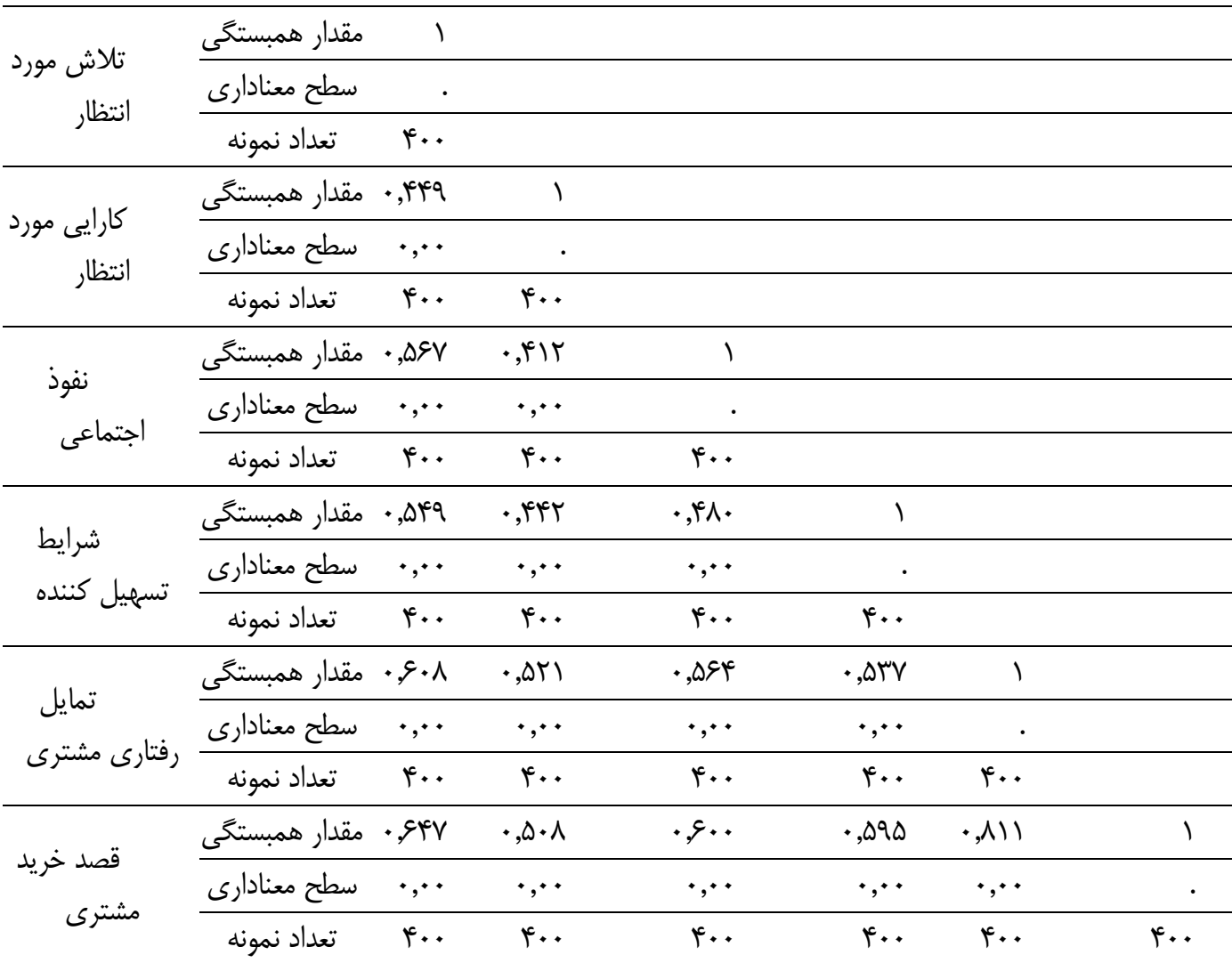

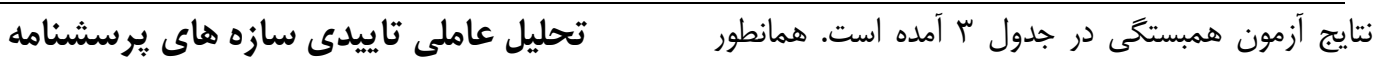

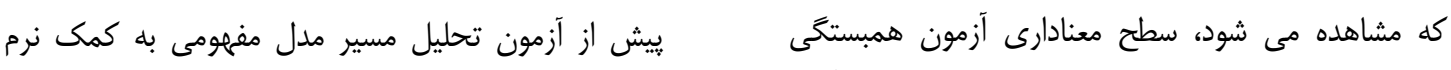

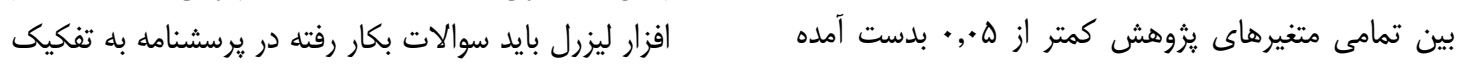

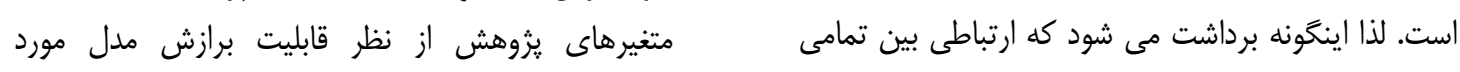

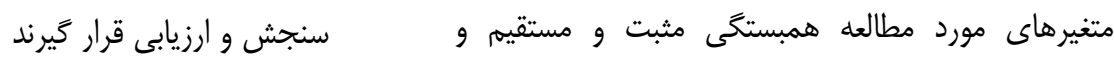

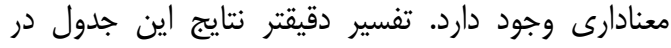
بخش بررسى فرضيات آورده شده است. جدول ع. تحليل عاملى تاييدى سازه هاى يرسشنامه

\begin{tabular}{|c|c|c|c|c|c|c|}
\hline نتيجه & ضايايى & كرونباخ & $\begin{array}{c}\text { مقدار } \\
\text { t }\end{array}$ & مقدار بار عاملى استاندارد & سوالات برسشنامه & متغيرها \\
\hline مطلوب & \multirow{4}{*}{$\cdot, \mathrm{VV}$} & \multirow{4}{*}{ r, ২৯. } & 10,99 & $\cdot, \gamma \Delta$ & Q1 & \multirow{4}{*}{ تلاش مورد انتظار } \\
\hline مطلوب & & & $\mid \mathrm{V}, \Delta \mathrm{\phi}$ & $\cdot \wedge 1$ & Q2 & \\
\hline مطلوب & & & $1 F, \Delta r$ & •, V. & Q3 & \\
\hline مطلوب & & & 9,99 & $\cdot, \Delta 1$ & Q4 & \\
\hline مطلوب & \multirow{3}{*}{ •, v • } & \multirow{3}{*}{$\cdot, V \cdot r$} & 14,98 & •, & Q5 & \multirow{3}{*}{ كارايى مورد انتظار } \\
\hline مطلوب & & & $1 r, v g$ & .91 & Q6 & \\
\hline مطلوب & & & $11, \cdot r$ & $\cdot, \Delta q$ & Q7 & \\
\hline مطلوب & \multirow{3}{*}{$\cdot, V \mu$} & \multirow{3}{*}{ •, Vॅq } & $1 f, \Delta \wedge$ & $\cdot, r)$ & Q8 & \multirow{3}{*}{ فوذ اجتماعى } \\
\hline مطلوب & & & $|V, 1|$ & $\cdot, \lambda$ & Q9 & \\
\hline مطلوب & & & $\mid T, M T^{c}$ &.,$g r$ & Q10 & \\
\hline
\end{tabular}




\begin{tabular}{|c|c|c|c|c|c|c|}
\hline نتيجه & 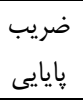 & كرونباخ & مقدار & مقدار بار عاملى استاندارد & سوالات يرسشنامه & متغيرها \\
\hline مطلوب & & & 1,99 & $\cdot, \uparrow \wedge$ & Q11 & \\
\hline مطلوب & \multirow{3}{*}{$\cdot, \lambda r$} & \multirow{3}{*}{$\cdot, \lambda r \cdot$} & $10, r q$ & $\cdot, \mathrm{V}$ & Q12 & \multirow{3}{*}{ شرايط تسهيل كننده } \\
\hline مطلوب & & & IV,IT & $\cdot, \mathrm{vq}$ & Q13 & \\
\hline مطلوب & & & $I V, \Delta T$ & $\cdot, \wedge 1$ & Q14 & \\
\hline مطلوب & \multirow[t]{3}{*}{$\cdot, \wedge \vee$} & \multirow[t]{3}{*}{$\cdot, \lambda \vee$} & $1 \Lambda, r$. & $\cdot, \wedge 1$ & Q15 & \multirow[t]{3}{*}{ تمايل رفتارى مشترى } \\
\hline مطلوب & & & $r \cdot 91$ & $\cdot, 19$ & Q16 & \\
\hline مطلوب & & & IVET & $\cdot, \mathrm{Vq}$ & Q17 & \\
\hline مطلوب & \multirow[t]{3}{*}{$\cdot, \mathrm{VV}$} & \multirow[t]{3}{*}{$\cdot, \vee \vee \vee$} & $18, \vee \cdot$ & $\cdot, \wedge \mathrm{V}$ & Q18 & \multirow[t]{3}{*}{ قصد خريد مشترى } \\
\hline مطلوب & & & IQ & $\cdot, \wedge$ & Q19 & \\
\hline مطلوب & & & $1 \cdot, V r$ & $\cdot, \Delta \Delta$ & Q20 & \\
\hline
\end{tabular}

تتيجه مىشود كه مقدار ضرايب آلفاى كرونباخ ، پايايى تركيبى براى تمامى سازهها مورد قبول مىباشند.

\section{شاخصهاى برازش مدل}

جهت تاييد مدل تحليل عاملى و مستند بودن نتايج حاصله

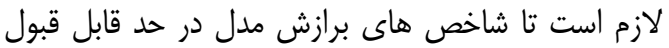
قرار كيرد. در جدول زير شاخصهاى مورد استفاده به همراه

$$
\text { مقادير آن آمده است. }
$$

تحليل عاملى تاييدى سازه هاى برسشنامه بكار برده شده

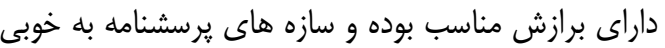
متغيرهاى مربوطه را نشان مى دهند.

\section{تجزيه و تحليل فرضيات يزوهش مئ}

از آماره t و ضريب بتاى ركرسيونى(ضريب مسير) جهت بررسى فرضيات استفاده شده است. جهت بررسى فرضيات تحقيق حاضر متغيرهاى تحقيق در نرم افزار ليزرل ايجاد شد. قبل از تاييد روابط برديات ساختارى بايد از مناسب بودن و برازش مطلوب اطمينان

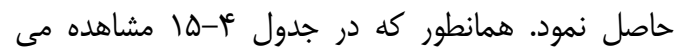

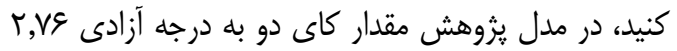

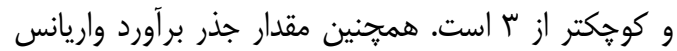

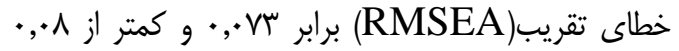
است. همجنين شاخص برازندگى تطبيقى(CFI)، شاخص

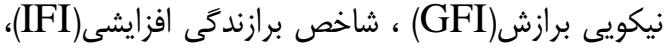

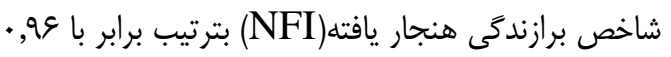

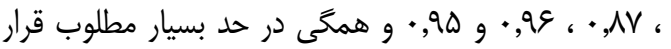
دارند، يس مدل برازش خوبى را نشان داده است.
همانطور كه در جدول بالا مشاهده مى شود، مقدار بار عاملى استاندارد شده براى تمامى سوالات بيشتر از هاء /. مى باشد و با توجه به اينكه تمامى اعداد معنادارى بين

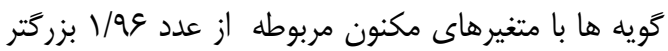

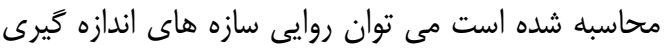

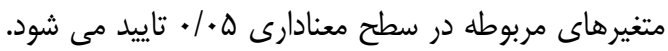
بنابراين نياز به تغيير يا حذف سوالى در مدل و يرسشنامه

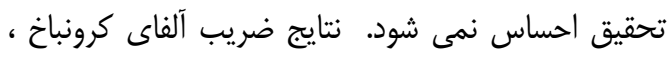

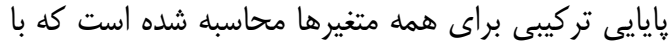

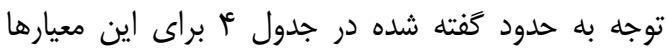
جدوله. نتايج شاخصهاى برازش مدالهای عاملى تاييدى

\begin{tabular}{|c|c|}
\hline بر آورد & مشخصه \\
\hline T,VG & 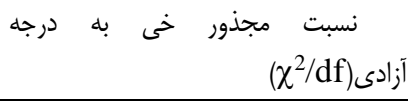 \\
\hline$\cdot, \cdot V^{c}$ & تقريب(RMSEA جزاورد) واريانس خطاى \\
\hline$\cdot, 9 \Delta$ & شاخص نرم شده برازندگى(NFI) \\
\hline$\cdot, 99$ & شاخص برازندگى تطبيقى(CFI) \\
\hline$\cdot, 99$ & برازش فزاينده(IFI) \\
\hline$\cdot, \wedge \mathrm{V}$ & شاخص نكويى برازش(GFI) \\
\hline
\end{tabular}

همانطور كه در جدول ه ملاحظه مى شود، در مدل تحليل

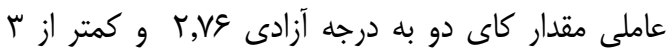
است. همجنين مقدار جذر برآورد واريانس خطاى تقري برابر با سل• (RMSEA) همجنين شاخص برازندگى تطبيقى (CFI) ، شاخص

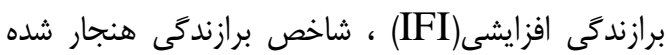
و شاخص نيكويى برازش (NFI)

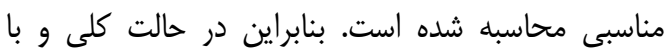
توجه به شاخص هاى محاسبه شده مى توان برازش

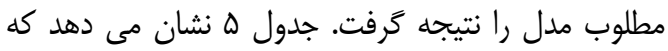




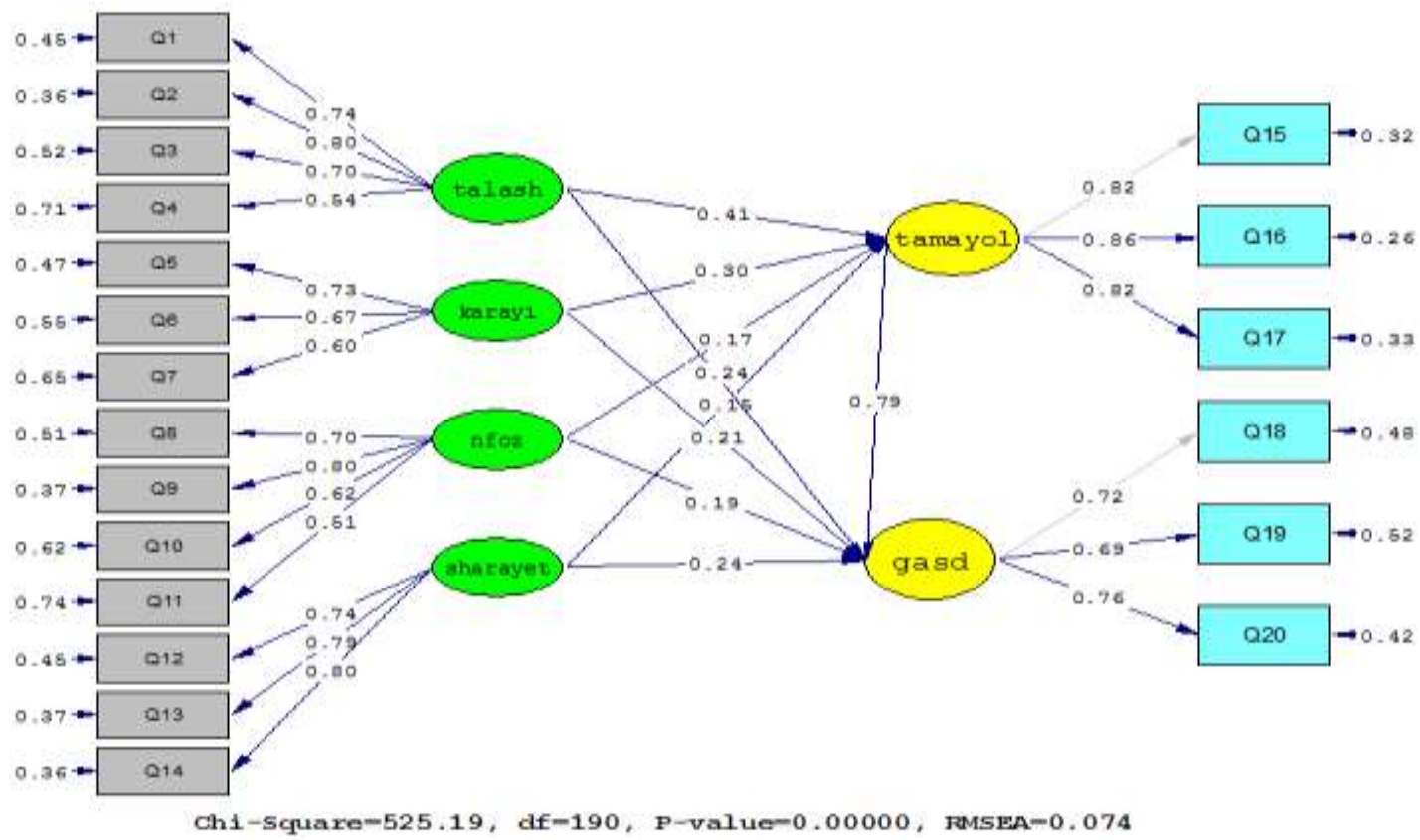

شكل r. ضرايب مسير استاندارد شده بين متغيرهاى مورد مطالعه

نمودار زير مدل تحقيق بر اساس ضرايب معنادارى تى را نشان مى دهد.

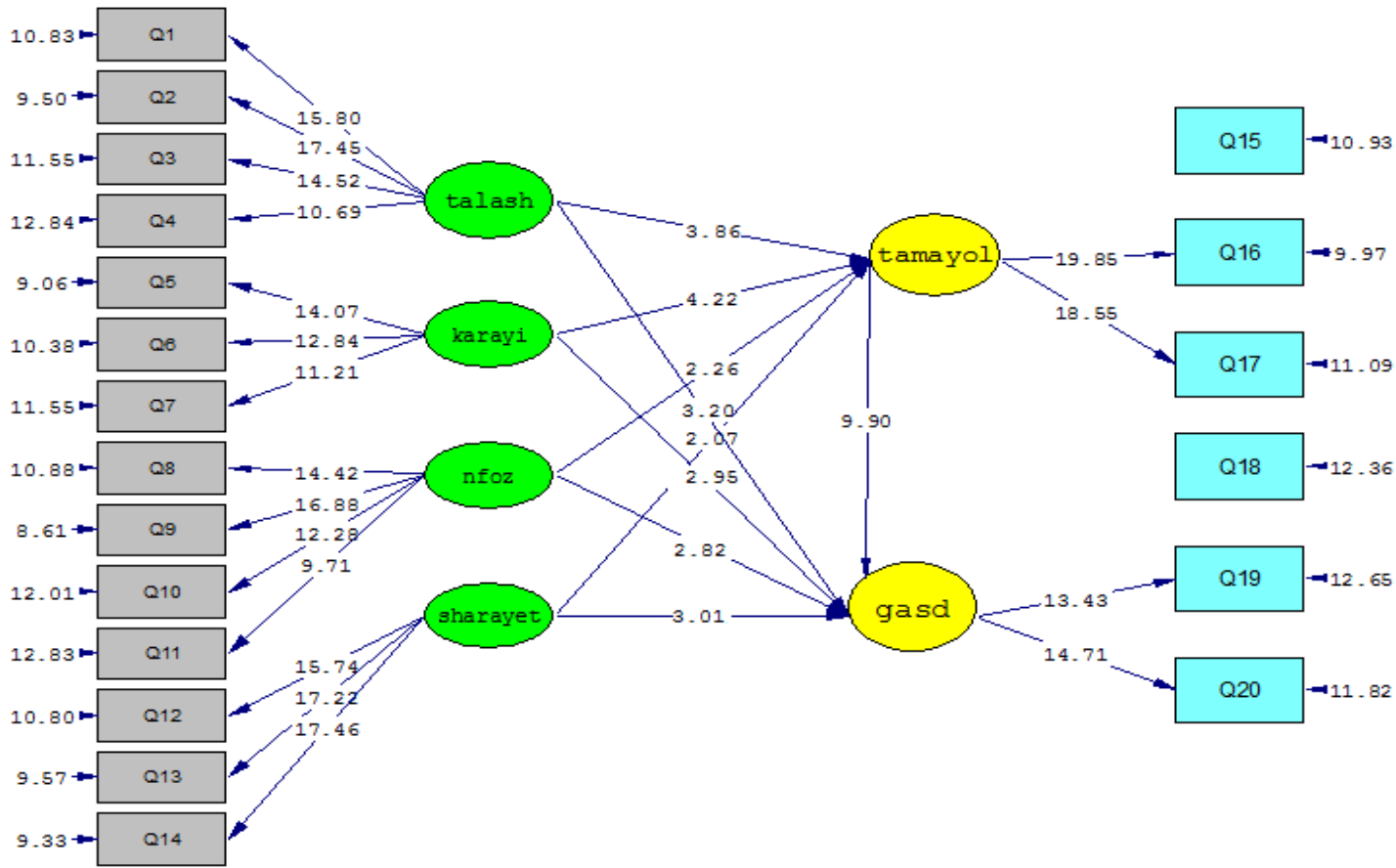

Chi-Square $=525.19, \mathrm{df}=190, \mathrm{P}$-value $=0.00000, \mathrm{RMSEA}=0.074$

شكل س.مقدار آماره تى بين متغيرهاى مورد مطالعه

نتايج حاصل از بررسى هاى فرضيه اول تا نهم تحقيق در جدول زير آمده است. 
جدولح.نتايج ضريب ركر سيونى و معنادارى اثر متغيرهاى تحقيق

\begin{tabular}{|c|c|c|c|c|c|c|}
\hline \multirow{2}{*}{ نتيجه } & \multicolumn{2}{|c|}{ همبستخى ييرسون } & \multirow{2}{*}{ 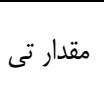 } & \multirow{2}{*}{ ضريب } & \multirow{2}{*}{ مسير مستقيم } & \\
\hline & sig & $\mathrm{r}$ & & & & \\
\hline تاييد & $\cdot, \cdot$ & $\cdot .9 \cdot 1$ & r,A & $\cdot,+1$ & تلاش مورد انتظار > تمايل رفتارى مشترى & 1 \\
\hline تاييد & $\bullet, \cdot$ & $\cdot \Delta, \Delta$ & R,tr & $\cdot, r \cdot$ & كارايى مورد انتظار > تمايل رفتارى مشترى & r \\
\hline تاييد & $\cdot, \cdot \cdot$ & $\cdot \Delta \& Y$ & retre & $\cdot, \mathrm{IV}$ & نفوذ اجتماعى × تمايل رفتارى مشترى & r \\
\hline تاييد & $\cdot, \cdot \cdot$ & • DUV & $t, \cdot \mathrm{r}$ & $\cdot, 10$ & شرايط تسهيل كننده تمايل رفتارى مشترى & r \\
\hline تاييد & $\cdot, \cdot \cdot$ &., $94 \mathrm{~V}$ & r,r. & $\cdot, r 4$ & تلاش مورد انتظار قصد خريد مشترى & $\Delta$ \\
\hline تاييد & $\cdot, \cdot \cdot$ & $\cdot, \infty \cdot \Lambda$ & r,qه & $\cdot, r)$ & كارايى مورد انتظار × قصد خريد مشترى & 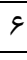 \\
\hline تاييد & $\cdot, \cdot \cdot$ & $\cdot .9 \cdot$ & r,Ar & $\cdot, 19$ & نفوذ اجتماعى ث قصد خريد مشترى & v \\
\hline تاييد & $\cdot, \cdot \cdot$ & $\cdot, \Delta 9 \Delta$ & $r, \cdot 1$ & $\cdot$ r Y & شرايط تسهيل كننده ٪ قصد خريد مشترى & $\wedge$ \\
\hline تاييد & $\cdot, \cdot \cdot$ & $\cdot, \wedge 11$ & १,१. & $\cdot, \mathrm{V} 9$ & تمايل رفتارى مشترى † قصد خريد مشترى & 9 \\
\hline
\end{tabular}

كاربردى كردن هر خه بهتر إيليكيشن خود استفاده كنند. با

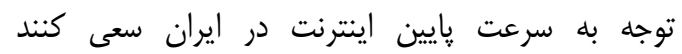

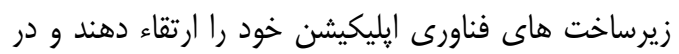

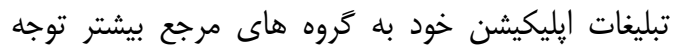
كنند هرا كه نفوذ اجتماعى إيليكيشن از عوامل مهره ترغيب افراد براى استفاده از خدمات شركت است. با توجه

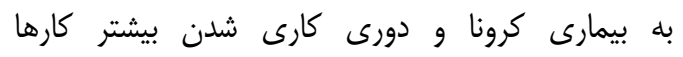

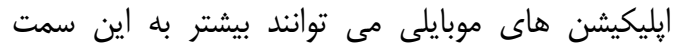

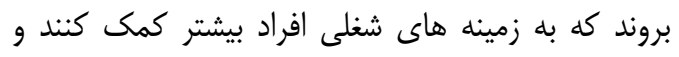

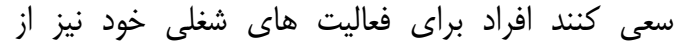
إيلكيشين هاى موبايلى استفاده كنند.
همانطور كه در جدول فوق ملاحظه مى شود، خون مقدار

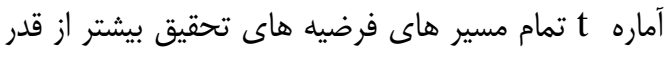

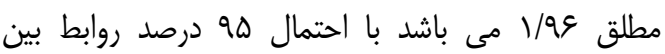

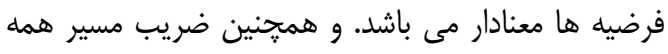
روابط مثبت است مى توان كفت هر 9 فرضيه تحقيق تاييد

$$
\text { مى شود. }
$$

\section{بحث بر روى نتايج تحقيق و ييشنهادات}

امروزه با توجه به شيوع بيمارى كويدوا يا يا همان كرونا

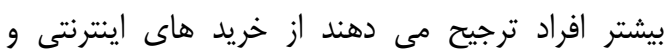

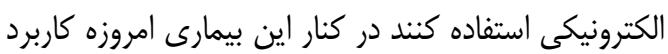
تلفن همراه و در دسترس بودن اينترنت كسب و كارها رانيا

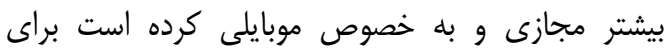
همين شاهد إيلكيشين هاى موبايلى زيادى هستيم كه هر بر برد

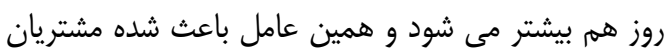

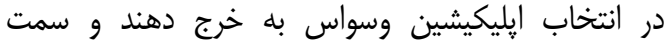
إيلكيشين هاى كه خدمات بهتر، سريع تر و از همه مهرمتر امن تر مى دهند بروند در اين تحقيق سعى كرديم با توجه

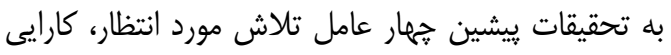

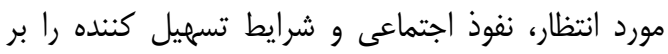

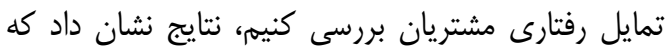

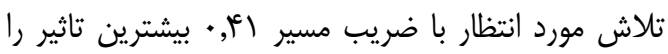
بر تمايل رفتارى مشتريان داشت در واقع راحتى استفاده از إيليكيشن در استفاده افراد موثر بود و افراد بيشتر به دئ دنبال إيلكيشن هايى بودند كه بتوانند راحت تر استفاده كنند.

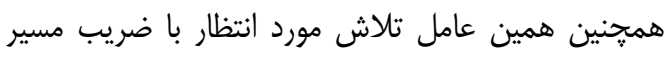
Fَ

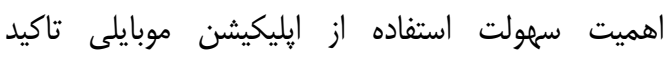
داشت.لذا به شركت هايى كه كسب و كار موبايلى دارند

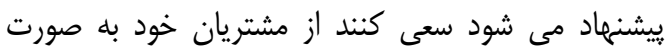
دوره اى از نحوه عملكرد و استفاده از إيليكيشن هاى إنى

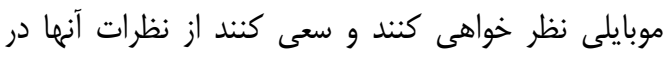




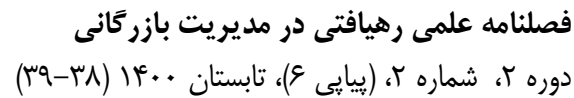

\section{Refrences:}

Lu, Y., Papagiannidis, S., \& Alamanos, E. (2019). Exploring the emotional antecedents and outcomes of technology acceptance. Computers in Human Behavior, 90, 153-169.

Macaulay, M., \& Gregory, R. (2016). So Near Yet So Far: Implications for the Organised Crime and Anti-Corruption Legislation Bill. The Journal of Criminal Law, 80(1), 17-27.

Miltgen, C. L., Popovič, A., \& Oliveira, T. (2013). Determinants of end-user acceptance of biometrics: Integrating the "Big 3" of technology acceptance with privacy context. Decision Support Systems, 56, 103-114.

Oliveira, T., Thomas, M., Baptista, G., \& Campos, F. (2016). Mobile payment: Understanding the determinants of customer adoption and intention to recommend the technology. Computers in Human Behavior, 61, 404-414.

Ozturk, A. B. (2016). Customer acceptance of cashless payment systems in the hospitality industry. International Journal of Contemporary Hospitality Management, 28(4), 801-817.

Riffai, M. M. M. A., Grant, K., \& Edgar, D. (2012). Big TAM in Oman: Exploring the promise of on-line banking, its adoption by customers and the challenges of banking in Oman. International Journal of Information Management, 32 (2), 239-250.

Rogers, E. M. (1995). Lessons for guidelines from the diffusion of innovations. Joint Commission Journal on Quality and Patient Safety, 21(7), 324-328.

San Lim, Y., Heng, P. C., Ng, T. H., \& Cheah, C. S. (2016). Customers' online website satisfaction in online apparel purchase: A study of Generation $\mathrm{Y}$ in Malaysia. Asia Pacific Management Review, 21(2), 74-78.

Sharma, S. K., Govindaluri, S. M., Al-Muharrami, S., \& Tarhini, A. (2017). A multi-analytical model for mobile banking adoption: A developing country perspective. Review of International Business and Strategy, 27(1), 133-148.

Soopramanien, D. G., \& Robertson, A. (2007). Adoption and usage of online shopping: An empirical analysis of the characteristics of "buyers""browsers" and "non-internet shoppers". Journal of Retailing and Consumer Services, 14(1), 73-82.

Su-Wen, C. (2011). A study of customers' intention to use internet banking: an integrated model. In Proceedings of the International Conference on Business and Information, Bangkok, Thailand. Retrieved
Afshan, S., \& Sharif, A. (2016). Acceptance of mobile banking framework in Pakistan. Telematics and Informatics, 33(2), 370-387.

Akturan, U., \& Tezcan, N. (2012). Mobile banking adoption of the youth market. Marketing Intelligence \& Planning, 30(4), 444-459.

Amin, H., Baba, R., \& Muhammad, M. Z. (2007). An analysis of mobile banking acceptance by Malaysian customers. Sunway academic journal, 4, 1-12.

Baptista, G., \& Oliveira, T. (2015). Understanding mobile banking: The unified theory of acceptance and use of technology combined with cultural moderators. Computers in Human Behavior, 50, 418-430.

Cao, Q., \& Niu, X. (2019). Integrating contextawareness and UTAUT to explain Alipay user adoption. International Journal of Industrial Ergonomics, 69, 9-13.

Chong, A. Y. L., Chan, F. T., \& Ooi, K. B. (2012). Predicting consumer decisions to adopt mobile commerce: Cross country empirical examination between China and Malaysia. Decision Support Systems, 53(1), 34-43.

Dwivedi, Y. K., Rana, N. P., Jeyaraj, A., Clement, M., \& Williams, M. D. (2017). Re-examining the unified theory of acceptance and use of technology (UTAUT): Towards a revised theoretical model. Information Systems Frontiers, 1-16.

Gefen, D., Karahanna, E., \& Straub, D. W. (2003). Trust and TAM in online shopping: An integrated model. MIS quarterly, 27(1), 5190.

Gupta, B., Dasgupta, S., \& Gupta, A. (2008). Adoption of ICT in a government organization in a developing country: An empirical study. The Journal of Strategic Information Systems, 17(2), 140-154.

Khan, S. A., Liang, Y., \& Shahzad, S. (2015). An empirical study of perceived factors affecting customer satisfaction to re-purchase intention in online stores in China. Journal of Service Science and Management, 8(03), 291.

Koksal, M. H. (2016). The intentions of Lebanese consumers to adopt mobile banking. International Journal of Bank Marketing, 34(3), 327-346.

Li, Z., \& Bai, X. (2010). Influences of perceived risk and system usability on the adoption of mobile banking service. In International Symposium on Computer Science and Computational Technology (ISCSCT) (Vol. 
فصلنامه علمى رهيافتى در مديريت بازر كانى، دوره ז، شماره ז، تابستان .. If

on December 12th.

Svantesson, D., \& Clarke, R. (2010). Privacy and consumer risks in cloud computing. Computer law \& security review, 26(4), 391397.

Venkatesh, V., Morris, M. G., Davis, G. B., \& Davis, F. D. (2003). User acceptance of information technology: Toward a unified view. MIS quarterly, 425-478.

Wang, W. T., Wang, Y. S., \& Liu, E. R. (2016). The stickiness intention of group-buying websites: The integration of the commitment-trust theory and e-commerce success model. Information \& Management, 53(5), 625-642. 